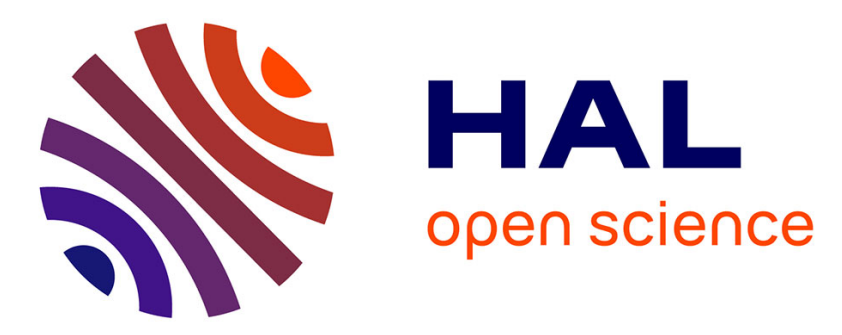

\title{
A new modeling approach to define marine ecosystems food-web status with uncertainty assessment
}

Aurélie Chaalali, Blanche Saint-Béat, Géraldine Lassalle, François Le Loc'h, Samuele Tecchio, Georges Safi, Claude Savenkoff, Jérémy Lobry, Nathalie Niquil

\section{To cite this version:}

Aurélie Chaalali, Blanche Saint-Béat, Géraldine Lassalle, François Le Loc'h, Samuele Tecchio, et al.. A new modeling approach to define marine ecosystems food-web status with uncertainty assessment. Progress in Oceanography, 2015, 135, pp.37-47. 10.1016/j.pocean.2015.03.012 . hal-01158158

\section{HAL Id: hal-01158158 https://hal.science/hal-01158158}

Submitted on 29 May 2015

HAL is a multi-disciplinary open access archive for the deposit and dissemination of scientific research documents, whether they are published or not. The documents may come from teaching and research institutions in France or abroad, or from public or private research centers.
L'archive ouverte pluridisciplinaire HAL, est destinée au dépôt et à la diffusion de documents scientifiques de niveau recherche, publiés ou non, émanant des établissements d'enseignement et de recherche français ou étrangers, des laboratoires publics ou privés. 
A new modeling approach to define marine ecosystems food-web status with

$$
\text { uncertainty assessment }
$$

Aurélie Chaalali ${ }^{1 *}$, Blanche Saint-Béat ${ }^{1,2}$, Géraldine Lassalle ${ }^{3}$, François Le Loc' $h^{4}$, Samuele Tecchio $^{1}$, Georges Safi ${ }^{1}$, Claude Savenkoff ${ }^{5}$, Jérémy Lobry ${ }^{3}$, Nathalie Niquil ${ }^{1}$.

${ }^{1}$ Unité Mixte de Recherche Biologie des ORganismes et Ecosystèmes Aquatiques (BOREA), MNHN, UPMC, UCBN, CNRS-7208, IRD-207, Université de Caen Basse Normandie, Esplanade de la Paix, 14032 Caen, France; nathalie.niquil@unicaen.fr; georges.safi@unicaen.fr; samuele.tecchio@unicaen.fr

${ }^{2}$ Unité Mixte de Recherche LIttoral ENvironnement et Sociétés, Université de la Rochelle, Institut du Littoral et de l'Environnement, 2 rue Olympe de Gouges, 17000 La Rochelle, France; blanche.saintbeat@gmail.com

${ }^{3}$ Irstea - Aquatic Ecosystems and Global Changes Unit, 50 avenue de Verdun, 33612 Gazinet Cestas cedex, France; geraldine.lassalle@irstea.fr; jeremy.lobry@irstea.fr

${ }^{4}$ Unité Mixte de Recherche Laboratoire des Sciences de l'Environnement Marin (CNRS/UBO/IRD/Ifremer), Institut Universitaire Européen de la Mer, Rue Dumont d'Urville, 29280 Plouzané, France; francois.le.loch@ird.fr

${ }^{5}$ Pêches et Océans Canada, Institut Maurice-Lamontagne, 850 route de la Mer, Mont-Joli, Québec G5H 3Z4, Canada; claude.savenkoff@dfo-mpo.gc.ca

*Corresponding author. E-mail: aurelie.chaalali@ifremer.fr, +33. (0)2 31.56.52.94 
2 Ecosystem models are currently one of the most powerful approaches used to project and analyse the consequences of anthropogenic and climate-driven changes in food web structure and function. The modeling community is however still finding the effective representation of microbial processes as challenging and lacks of techniques for assessing flow uncertainty explicitly. A linear inverse model of the Bay of Biscay continental shelf was built using a Monte Carlo method coupled with a Markov Chain (LIM-MCMC) to characterize the system's trophic food-web status and its associated structural and functional properties. By taking into account the natural variability of ecosystems (and their associated flows) and the lack of data on these environments, this innovative approach enabled the quantification of uncertainties for both estimated flows and derived food-web indices. This uncertainty assessment constituted a real improvement on the existing Ecopath model for the same area and both models results were compared.

Our results suggested a food web characterized by main flows at the basis of the food web and a high contribution of primary producers and detritus to the entire system input flows. The developmental stage of the ecosystem was characterized using estimated Ecological Network Analysis (ENA) indices; the LIM-MCMC produced a higher estimate of flow specialization (than the estimate from Ecopath) owing to better consideration of bacterial processes. The results also pointed to a detritus-based food-web with a web-like structure and an intermediate level of internal flow complexity, confirming the results of previous studies. Other current research on ecosystem model comparability is also presented.

Key words: ecosystem; food web; Ecological Network Analysis indices; linear inverse model; Bay of Biscay 


\section{Introduction}

Natural systems are known to demonstrate strong spatial and temporal variability (Frontier et al., 2008), however scientists encounter problems relating to the quantification of uncertainty when trying to represent an environment at a particular point in space or time, especially in trophic modeling. Several methods have been developed to assess the food-web properties of an ecosystem; linear inverse models using a Monte Carlo method coupled with Markov Chain (LIM-MCMC; Van der Meersche et al., 2009; van Oevelen et al., 2010) are an innovative technique for quantifying uncertainty in both flows and indices relating to the structural and functional properties of an ecosystem (Niquil et al., 2012). The idea of using a LIM-MCMC to describe each flow in terms of a range of possible values rather than a single value, was first proposed by Donali et al. (1999) and developed further in more recent studies (Leguerrier, 2005; Kones et al., 2006). The LIM-MCMC approach makes it possible to take into account flow variability, which is usually the result of uncertainties in observational data (van Oevelen et al., 2010; Niquil et al., 2012). The uncertainty is integrated into the model by defining minimum and maximum boundaries for each flow. Because it takes into account uncertainty in flow, the method also permits a distinction to be drawn between local data (from the period or region for which a solution was tested) and data from a different but related ecosystem. This new approach enables minimum and maximum flow values and average estimates with standard deviations to be computed on the basis of a given number of flow solutions; a similar approach can be used with indices related to the structural and functional properties of an ecosystem (van Oevelen et al., 2010; Niquil et al., 2012).

Linear inverse methods are also well suited to describing eco-physiological processes operating in the microbial food web, such as plankton excretion and bacterial uptake of dissolved organic carbon. This is important because there is also consensus amongst the scientific community on the urgent need for comprehensive incorporation of microbial 
processes into models in order to provide a holistic understanding of ecosystem structure and function, from prokaryotes to top predators (Davidson, 1996; Li et al., 2011; Saint-Béat, 2012). The LIM approach has been used quite frequently in aquatic plankton ecology (e.g., Vézina and Pace, 1994; Vézina and Savenkoff, 1999; Niquil et al., 2001; Marquis et al., 2007) but despite its advantages it has rarely been applied to larger marine ecosystems, an exception being a study of the Gulf of St Lawrence (Savenkoff et al., 2007; Rioual, 2012).

The Marine Strategy Framework Directive (MSFD - Directive 2008/56/EC) established criteria and associated indicators (MSFD - Decision 2010/477/EC) for what the MSFD refers to as "Good Environmental Status" (GES) in European Waters. Evaluation of the initial list revealed that it was inadequate for determining whether a marine food web had reached GES (Rombouts et al., 2013). A list of nine food web indicators which would better capture food web characteristics (i.e., structure, functioning and dynamics), and thus complement the existing GES definition, was submitted to the OSlo and PARis (OSPAR) Intersessional Correspondence Group For Coordination Of Biodiversity Assessment and Monitoring (ICGCOBAM; International Council for the Exploration of the Sea [ICES], 2013; Niquil et al., 2014b). Two of these indices are related to the concept of fishing down the food-web (Pauly et al., 1998) by measures of size (Large Fish Index) or mean trophic level of predatory fishes (Marine Trophic Index). Two other are related to trophic guilds, either composed of fish or plankton. The Ecological Network Analysis indices were among these candidate indicators and are currently being assessed, in order to look for holistic and functional indicators.

Ecological network analysis (ENA; Ulanowicz, 1986) was developed to identify holistic structural and functional properties which are not directly observable and can only be detected by analysis of within-system interactions (Fath et al., 2007). The main challenge for ENA is to capture an ecosystem's entire food web in terms of a limited number of indices. Previous research has suggested that the values of ENA indices varied according to the pressures on a 
given ecosystem, and among habitats (Patrício et al., 2004; Dame and Christian, 2007; Coll et al., 2009; Pranovi and Link, 2009; Baeta et al., 2011; Niquil et al., 2014a). ENA index values derived from a LIM-MCMC include a measure of the uncertainty of the estimates, unlike those derived from other over-constrained models. Information about uncertainty can be crucial as some changes in the variance of such indices may reflect an important shift in the trophic status of an ecosystem, e.g., changes in the Baltic Sea (Tomczak et al., 2013) and, more recently, changes in the Ionian Sea in response to climate changes (Niquil et al., submitted).

The present work was methodological; our focus was on documenting a non-familiar modeling approach when considering large marine ecosystems. The LIM-MCMC method would address two of the main weaknesses typical of food web modeling, i.e., the model should include an uncertainty assessment and provide a better representation of low-trophiclevel processes. A LIM-MCMC was set up for the Bay of Biscay continental shelf. The full presentation of steps and issues related to the LIM-MCMC construction and uncertainty analysis were provided. Then, the food web status of the Bay of Biscay and its structural and functional properties were characterized through the calculation of a range of ENA indices. Finally, ecological conclusions derived from the LIM-MCMC were compared with those obtained with a pre-existing Ecopath model of the same ecosystem (Lassalle et al., 2011). 
2. Material and Methods

2.1. Study area

The Bay of Biscay is a Gulf of the North-East Atlantic Ocean, located off the west coast of France and the northern coast of Spain (Figure 1) between $48.5^{\circ} \mathrm{N}$ and $43.5^{\circ} \mathrm{N} ; 008^{\circ} \mathrm{W}$ and $003^{\circ} \mathrm{W}$. This ecoregion is subject to a wide variety of environmental processes such as coastal upwelling, coastal run-off and river plumes, seasonal currents, eddies, internal waves and tidal fronts (Planque et al., 2004). Five main rivers supply fresh water to the sea: the Loire, the Garonne-Dordogne, the Adour, the Vilaine and the Charente; these rivers modulate the salinity of the plume regions. All these processes influence the biological communities of the Gulf, especially the plankton communities, and affect the functioning of the whole food-web (Varela, 1996; Lampert, 2001). The Bay of Biscay supports a multifleet fishery, primarily operated by French and Spanish boats, which exploits a wide range of species using diverse types of fishing gear (Rochet et al., 2012). For this study we considered only ICES divisions VIIIa and VIIIb (ICES; www.ices.dk), between the $30 \mathrm{~m}$ and $150 \mathrm{~m}$ isobaths, giving a total surface area of $102,585 \mathrm{~km}^{2}$.

\subsection{Model complexity}

Some of the input parameters for the LIM-MCMC were taken from the Ecopath model (diet composition, pedigrees, Production/Biomass ( $\mathrm{P} / \mathrm{B})$ ratios). These parameters were used to define compartment interactions, mass balances and some flows constraints (e.g., production constraints).

The first step in compartment model construction is to define the protagonists of the various interactions and how they are aggregated into compartments (Johnson et al., 2009; Niquil et al., 2012). The species composition of our model (Tables 1 and 2) varied very little from that presented by Lassalle et al. (2011; supplementary material); the main differences between the 
two models are structural. In this study the number of compartments was reduced by a factor of roughly two, from 32 to 18 (Tables 1 and 2). The aim of this simplification of structure was threefold: (i) to describe and constrain the flows without applying the same constraints to different compartments; (ii) to characterize all compartments with the same precision; there was not sufficient ecological data from all the 32 Ecopath compartments to include them as stand-alone compartments in the LIM; and (iii) to achieve a sensible balance between the time required to run simulations and the level of detail in which flow values were explored.

Ecopath compartments which were mono-specific, and for which there was either (i) insufficient physiological data, or (ii) which occupied the same trophic position in the upper food web (i.e., the five marine mammal compartments, the two seabird compartments and two cephalopod groups), were combined (Tables 1 and 2). The Ecopath model used four compartments for demersal fish on the basis of their trophic ecology; we chose to distinguish strictly benthivorous demersal fishes from other demersal species. The Ecopath model used five mono-specific compartments to represent small pelagics; in the LIM-MCMC pelagic fishes were separated into two groups based on feeding habits, pelagic piscivorous and strictly pelagic planktivorous (Table 2). Necrophageous and carnivorous invertebrates were aggregated on the basis of the reduced number of invertebrate species with a necrophageous diet in the LIM-MCMC. In the LIM-MCMC, the other four invertebrate compartments of the Ecopath model were aggregated on the basis of the commonly used dichotomy between deposit and suspension invertebrate feeders. The two size-classes of phytoplankton were considered together. Discards, commonly regarded as dead organisms, were not distinguished from detritus (i.e., particulate organic matter, POC). Finally the LIM-MCMC included an additional dissolved organic carbon (DOC) group (Tables 1 and 2). The second step in defining the network topology, after the groups had been established, was the listing of all the 
possible flows between compartments and at the system margins (see Table S1 in Supplementary Material).

2.3. General principles and parameterization

The food-web model used was a linear inverse model based on the Monte Carlo Markov

Chain (LIM-MCMC; Van den Meersche et al., 2009; van Oevelen et al., 2010). It was defined by a combination of mass-balance equations (and potential in situ measures of flow expressed as complementary equations) and inequalities which constrain flow values. In most cases constraints were based on the eco-physiology of the species making up the model compartments (Niquil et al., 2012).

The linear equalities describing the system were typically expressed as a matrix calculation:

$$
\mathrm{A} \cdot \mathrm{r}=\mathrm{b}
$$
where $\mathrm{A}$ is the matrix of coefficients, $\mathrm{r}$ the vector of possible flows and $\mathrm{b}$ the vector of equality results.

The solution is based on finding the vector $r$ for which the equations are valid.

The system of equalities is underdetermined, so in most cases complementary inequalities were added to constrain the flows. The system of linear inequalities can be written as:

$$
\mathrm{G} \cdot \mathrm{r} \geq \mathrm{h} \quad(\text { Eq.2) }
$$

where $\mathrm{G}$ is the matrix of coefficients (inequality relationships) and h the vector of inequality values. These constraints reduced the area of the solution space to a polytope. Following this a mirror of the Monte-Carlo-Markov Chain technique (Van den Meersche et al., 2009) was applied to explore the polytope and describe all possible solutions.

\subsubsection{Equalities}


In this model, equalities were only described by mass-balance equations (Table S2); no nominal flow values were entered in the model to take into account the uncertainty in field data collected from an ecosystem. Model equalities captured the fact that, for each compartment considered in the model, input flows (i.e., imports or consumption) were equal to output flows (i.e., exports, production, respiration, production of detritus or egestion, and in some cases, excretion). The model assumed an intrinsic steady-state system in which biomasses were not changing and net migration (difference between emigration and immigration) was equal to zero or negligible on an annual scale. Mortality in the model was mainly due to predation and exports by fisheries, natural mortality other than predation, such as disease, was considered negligible in comparison with mortality by predation or fishing.

Eighteen mass-balance equations, one per compartment (Table S2), were set up in matrix form (matrix A). There were as many rows as there were mass-balance equations $(m=18)$ (Table S2). The columns of the matrix represent the flows; there were as many columns as there were flows $(n)$ in the food web (Table $\mathrm{S} 1)$. The vector of equality results $b(m \times 1)$ thus contains the right-hand sides of the mass-balance equations. Inverse methodology was then used to calculate a vector $r(n \times 1)$ with as many elements as there were columns in A. Vector $r$ represents the flows that, when multiplied by $\mathbf{A}$, approximates the vector $b$ (Eq. 1 ). The diet content matrix from the Ecopath model was used to determine coefficients for output predation flows in these equations. Additional predation flows were integrated (e.g., Marquis et al., 2007; Saint-Béat et al., 2013) on the same basis, especially those relating to consumption of bacteria in the system, roughly restricted to microzooplankton in the Ecopath model (Table 1 and Table S2 in Supplementary Material).

\subsubsection{Inequalities}


191 Constraints were added to the model, i.e., flow estimates were constrained between predefined minima and maxima (Table S3). Inequalities were included by filling a matrix $\mathbf{G}$ of $c$ $\mathrm{x} n$ where $c$ was the number of inequalities added to the model and $n$ the number of possible flows, with negative or positive coefficients between 0 and 1 (Eq. 2). The vector $h$ for the inequalities $(c \times 1)$ formed the right-hand side of the inequality relationship and thus had as many elements as there were rows in $\mathbf{G}$.

\section{Respiration}

Bacterial respiration was constrained by setting minimum and maximum values for DOC uptake by bacteria (Vézina and Savenkoff, 1999). Phytoplankton respiration was limited to 5 to $30 \%$ of gross primary production (GPP) in accordance with constraints set out by Vézina and Platt (1988). The lower boundary for respiration in zooplankton compartments was defined as $20 \%$ of their ingestion, in defining the upper boundary, the sum of their respiration, excretion and egestion was assumed to be less than $75 \%$ of their ingestion (Vézina and Pace, 1994). Respiratory constraints for meiofauna and benthic invertebrates were derived from van Oevelen et al. (2006) (Table S3).

\section{Excretion}

Bacteria, phytoplankton and micro- and meso-zooplankton excrete or exude carbon to the DOC compartment (Riemann et al., 1990). Because there is no precise method of estimating the transformation of particulate detritus into DOC (Pace et al., 1984), this constraint was not considered in the present model. Excretion flows for the four compartments mentioned above were constrained according to Vézina and Platt (1988) and Vézina and Savenkoff (1999) (Table S3).

\section{Egestion}

Egestion was constrained on the basis of assimilation efficiency (AE) rates found in the literature (Vézina and Platt, 1988; Scheiffarth and Nehls, 1997; Leguerrier, 2005; van 
Oevelen et al., 2006) (Table S3). AE rates were included for all compartments except cephalopods and marine mammals (low confidence or lack of information). AE is defined as the amount of carbon that is assimilated divided by the total amount of carbon ingested $\left(\sum\right.$ consumption) (van Oevelen et al., 2006):

$$
\mathrm{AE}=\frac{\sum \text { consumption-loss to detritus }}{\sum \text { consumption }}
$$

\section{Production}

Production estimates were obtained by multiplying the two key input parameters for the Ecopath model of the Bay of Biscay continental shelf food web, P/B ratios and biomass estimates. Inter-annual variations in compartment biomass multiplying by mean $\mathrm{P} / \mathrm{B}$ ratio were used to calculate minimum and maximum production for each compartment. The biomass values for the Ecopath model were the averages of annual estimates for the period 2000-2010. The lower bound for production was equal to the $\mathrm{P} / \mathrm{B}$ ratio multiplied by the lowest biomass recorded during this period and vice versa. At the time scale considered and for a given species, the variation of $\mathrm{P} / \mathrm{B}$ was negligible. Thus, we did not consider the variation of $\mathrm{P} / \mathrm{B}$ for the production estimation.

Gross Primary Production (GPP) was considered as an import to the phytoplankton compartment. Constraints on this flow are therefore described in the Imports section below.

\section{Growth efficiency}

Additional constraints on growth efficiencies (GEs) were added. GE is the ratio of production to ingestion, i.e., GE = Production/ Ingestion. According to Christensen and Pauly (1992), most consumer organisms have a GE between 10\% and 30\% (Table S3).

\section{Import}

Two main imports were considered in the present model, import to phytoplankton (GPP) and import of detritus. 
Estimates of GPP were derived from estimates of net primary production (NPP) from four

241 Earth system models (Bopp et al., 2013): the CESM1-BGC, the GFDL-ESM2G, the GFDL-

242 ESM2M and the NorESM1-ME. These four models were selected from the range of Earth

243 system models because they gave NPP estimates similar to SeaWifs observation data for our study area over the 1975-2005 period (Bopp et al., 2013). These estimates were also comparable to the NPP in situ value entered into the Ecopath model of the Bay of Biscay continental shelf. Minima and maxima were based on the 5th and 95th percentiles of model estimates.

Detritus imports from the five main rivers flowing into the Bay of Biscay were estimated from measurements of POC in estuaries (Abril et al., 2002) and mean annual river discharges (www.hydro.eaufrance.fr). Lower and upper bounds were related to inter-annual variability of river discharges over the 1998-2002 time period.

\section{Export}

Exports out of the system by commercial groups were mainly due to fishing. Estimates were based on international landing statistics for ICES divisions VIIIa and VIIIb for the 1998-2002 period. These data were complemented by data from the relevant ICES working groups, i.e., the WGCEPH for cephalopods (ICES, 2005a) and the WGMHSA for small pelagic fish (ICES, 2005b). Landings for the various exploited species in a compartment were summed. Lower and upper limits were derived from landing time series.

Exports of detritus (sedimentation to greater depths or transport of particulate matter by currents) were also considered, but no maximum or minimum constraints were applied owing to lack of information.

\section{Diet composition}

The Ecopath model gave pedigree index values which categorized the quality of data sources for the five main input parameters (biomass, $\mathrm{P} / \mathrm{B}$, consumption/biomass, diet composition, 
and commercial catches) (Christensen et al., 2008). These authors associated a default confidence interval with each pedigree index value. Thus, depending of the quality of the origin input, pedigree index values of $0,0.2,0.5,0.7$, and 1 correspond, for diet composition, to confidence intervals of $\pm 80 \%, \pm 80 \%, \pm 50 \%, \pm 40 \%$, and $\pm 30 \%$, respectively. The pedigree table for the Ecopath Bay of Biscay continental shelf food web model has recently been completed (Lassalle et al., 2014). Lower and upper limits for diet composition were based on the diet composition matrix of the Ecopath model and the related confidence intervals in the pedigree table.

\subsection{Data used in modeling}

Compartment production, import, and export data were estimated from scientific survey data (PELGAS cruises, MICRODYN, BIOMAN, and INTRIGAS surveys; Labry et al., 2002; Le Loc'h, 2004; Irigoien et al., 2009) collected during different seasons over the period 19942005 by the Institut Français de Recherche sur l'Exploitation de la MER (IFREMER), the AZTI-Tecnalia (a Technological Centre specialised in Marine and Food Research), and the Centre National de la Recherche Scientifique (CNRS). A full description is provided in Lassalle et al. (2011).

Fish stock data were taken from the ICES/ACFM advice report (ICES, 2004) and biomasses of fish species were estimated from annual autumn surveys of bottom-trawl catches in the Bay of Biscay (EVHOE IFREMER cruises). Pelagic fish biomasses were calculated from acoustic surveys conducted each spring in the Bay of Biscay (PELGAS IFREMER cruises).

Sea birds estimates were based on data from visual counting and identification and aerial surveys performed monthly between October 2001 and March 2002, and in August 2002, June 2003 and May 2004 (ROMER and ATLANCET surveys). Finally, data on marine mammals were obtained from (i) the July 2005 SCANS-II project (ship and aircraft surveys of 
small cetaceans in the European Atlantic); (ii) repeated extensive aerial surveys at different seasons between 2001 and 2004 (ROMER and ATLANCET surveys; Certain et al., 2008), and (iii) the monitoring of marine mammals via stranding and spring shipboard observations during the PELGAS IFREMER cruises (Certain et al., 2011).

\subsection{Model resolution}

The mirror technique described by Van Den Meersche et al. (2009) was used to compute a multitude of solutions and quantify uncertainty around all flows. Two parameters must be defined in order to use this technique: a number of iterations to optimize the exploration (or coverage) of the polytope of solutions and a 'jump' representing the mean distance between two consecutive solutions in a randomly chosen direction. For this study one million solutions were calculated with a jump equal to $100 \mathrm{kgC} \cdot \mathrm{km}^{-2} \cdot \mathrm{y}^{-1}$ which corresponded to an approximation of the median of the flow values. The jump was set up in order to get a good polytope exploration and also to get better estimations of small and large flows. All simulations were performed using the MATLAB software and the algorithm developed by Vézina and Campo (Bedford Institute of Oceanography, Fisheries and Oceans, Canada), which is a translation of the R package limSolve (Soetaert et al., 2009).

\subsection{Ecological network analysis}

Ecological network analysis (ENA; Ulanowicz, 1986) was used to compute several indices to characterize the structure and function of the Bay of Biscay continental shelf food web. To facilitate comparison of our model with the Ecopath model, we calculated values for the ENA indices estimated by Lassalle et al. (2011) for the Ecopath model, namely Total System Throughput (T..), Internal Relative Ascendency (Ai/Ci), Finn Cycling Index (FCI), System 
flows in a food web thus acts as a proxy for system activity or organization. The internal relative ascendency $(\mathrm{Ai} / \mathrm{Ci})$ ratio provides a relative measure of the degree of organization of a food web based only on internal flows and was directly issued from the Ecopath model. Finn (1980) proposed an index of the importance of recycling activity based on the percentage of flows involved in cycles. According to Ulanowicz (1986), CI and SOI values generally reflect the complexity of the linkages within an ecosystem (in terms of both structure and organization).

A LIM-MCMC MATLAB routine adapted from the one developed by Lebreton and Schartau (GKSS Research Center, Geesthacht, Germany) was used to compute one ENA index value for each flow solution estimated by the LIM-MCMC.

We also compared the Detritivory/Herbivory $(\mathrm{D} / \mathrm{H})$ ratio, calculated as the sum of flows originating from detritus and DOC compartments (detritus consumption) divided by the sum of flows from phytoplankton (phytoplankton consumption). The $\mathrm{D} / \mathrm{H}$ ratio measures the relative importance of detritivory and herbivory activity in a given system.

\subsection{Analysis of flows and ENA indices}

The general distribution of the flows estimated by the LIM-MCMC was assessed with two barplots, one including all estimated flows and the second restricted to the five flows with the highest mean values.

The structure of the food web was investigated by analyzing the input flows of the compartments; input flows were only compared for compartments which were defined similarly in both models. The position of Ecopath value inside or outside the range of values estimated by the LIM-MCMC was assessed. 
338 Respiration flows in the two models were also compared and cases in which the single

339 Ecopath value fell within the range of possible values predicted by LIM-MCMC were noted.

340 Values for the ENA indices which were estimated in both models were also compared and the

341 relative position of the Ecopath values analyzed.

342 We did not carry out any of the classic mean comparison tests because of the important size of 343 the samples (1 million observations in the LIM-MCMC vs. one Ecopath reference value); the 344 Markov-Chain used in the LIM-MCMC also meant that the independence of observations 345 criterion was not satisfied. However, we considered instances in which the Ecopath value fell 346 within the range estimated by the LIM-MCMC to be highly informative (and significant) even 347 without further analysis. 
Estimates of flows from the LIM-MCMC are given in the Supplementary Material (Table S1).

The highest flows in the food web were mainly related to phytoplankton production,

351 consumption, sedimentation or exudation (1-10), or to bacterial and detrital processes (80-98) (see Figure 2A and Table S1 in Supplementary Material). The flows with an average higher than $5 \cdot 10^{4} \mathrm{kgC} \cdot \mathrm{km}^{-2} \cdot \mathrm{y}^{-1}$ (Figure 2B) were: the GPP (1), $2.41 \cdot 10^{5} \pm 0.5 \cdot 10^{5} \mathrm{kgC} \cdot \mathrm{km}^{-2} \cdot \mathrm{y}^{-1}$; the phytoplankton sedimentation (2), $1.10 \cdot 10^{5} \pm 0.23 \cdot 10^{5} \mathrm{kgC} \cdot \mathrm{km}^{-2} \cdot \mathrm{y}^{-1}$ and the consumption of dissolved organic carbon by bacteria (98), $1.04 \cdot 10^{5} \pm 0.35 \cdot 10^{5} \mathrm{kgC} . \mathrm{km}^{-2} \cdot \mathrm{y}^{-}$ 1.

The two detrital groups (i.e. POC and DOC) and the phytoplankton compartment contributed to $18.8 \%, 10.8 \%$, and $31 \%$ of the total carbon input via river discharges and GPP, respectively. The estimated net allochthonous input of $502.65 \mathrm{kgC} \cdot \mathrm{km}^{-2} \cdot \mathrm{y}^{-1}$ of detritus was low in comparison with GPP $\left(2.41 \cdot 10^{5} \pm 0.5 \cdot 10^{5} \mathrm{kgC} \cdot \mathrm{km}^{-2} \cdot \mathrm{y}^{-1}\right)$. Detailed compartment input flows (sum of carbon entering a given compartment) are given in Figure 3. Comparison of estimated compartment input flows from the LIM-MCMC and the Ecopath model revealed a similar pattern, especially for first trophic level compartments; in both models there was a peak of activity associated with pelagic planktivores. Graphical comparison of compartment input flows for the two models (to assess whether the Ecopath estimate fell within the LIMMCMC estimated range) revealed that results were consistent for most groups; the main difference was in microzooplankton input flow estimates (average values were $7.8 \cdot 10^{4}$ $\mathrm{kgC} \cdot \mathrm{km}^{-2} \cdot \mathrm{y}-1$ for the LIM-MCMC and $2.8 \cdot 10^{5} \mathrm{kgC} \cdot \mathrm{km}^{-2} \cdot \mathrm{y}^{-1}$ for the Ecopath model).

Respiration flows accounted for $86.7 \%$ of the carbon output $\left(2.1 \cdot 10^{5} \mathrm{kgC} \cdot \mathrm{m}^{-2} \cdot \mathrm{y}^{-1}\right)$ of the system. The contribution from bacterial respiration (29.5\% of total respiration) was closely followed by meiofaunal respiration $(27.1 \%)$. Comparison of respiration estimates revealed that half the values for respiration flow estimated with the Ecopath model lay within the range 
373 of estimates given by the LIM-MCMC. The remaining estimates were evenly distributed, 374 suggesting that neither model systematically over- or under-estimated respiration flow. The 375 greatest differences in estimated respiration flow were for seabirds (LIM-MCMC: $533.44 \pm$ $189.58 \mathrm{kgC} . \mathrm{km}^{-2} \cdot \mathrm{y}^{-1}$; Ecopath: $16.42 \mathrm{kgC} \cdot \mathrm{km}^{-2} \cdot \mathrm{y}^{-1}$ ) and meiofauna (LIM-MCMC: $5.8 \cdot 10^{4} \pm$ $2.61 \cdot 10^{4} \mathrm{kgC} \cdot \mathrm{km}^{-2} \cdot \mathrm{y}^{-1}$; Ecopath: $\left.2000 \mathrm{kgC} \cdot \mathrm{km}^{-2} \cdot \mathrm{y}^{-1}\right)$.

LIM-MCMC estimates of T.. ranged from $7.35 \cdot 10^{5} \mathrm{kgC} \cdot \mathrm{km}^{-2} \cdot \mathrm{y}^{-1}$ to $8.44 \cdot 10^{5} \mathrm{kgC} \cdot \mathrm{km}^{-2} \cdot \mathrm{y}^{-1}$. The Ecopath model estimate, $9.4 \cdot 10^{5} \mathrm{kgC} \cdot \mathrm{km}^{-2} \cdot \mathrm{y}^{-1}$, was above the maximum LIM-MCMC estimate (Figure 4). Estimates of internal relative ascendency, which does not include external ascendency from the LIM-MCMC was $0.34 \pm 0.01$, which was higher than the Ecopath estimate, 0.22 .

The average cycling index value obtained from the LIM-MCMC was $0.13 \pm 0.01$, notably lower than the Ecopath estimate, 0.35. Comparison of $\mathrm{D} / \mathrm{H}$ ratios revealed that the Ecopath model estimate (1.32) was within the range of LIM-MCMC estimates $(0.46-1.84)$ and close to the mean LIM-MCMC estimate.

The LIM-MCMC estimate of CI was higher than the Ecopath model estimate (LIM-MCMC: 


\section{Discussion}

This study is one of the first attempts to model a large exploited marine ecosystem using the LIM-MCMC method. This innovative approach to modeling was developed for theoretical exploration of ecological networks; it enables uncertainties to be quantified and allows complex eco-physiological processes operating at the level of the food-web to be incorporated into models. Interestingly, the LIM-MCMC of the Bay of Biscay continental shelf provided results which confirmed and extended the findings derived from an earlier Ecopath model by Lassalle et al. (2011). The estimates produced by the two models differed little with respect to the flows analyzed and five ENA indices investigated, however comparison of values for more ENA indices and respiration flows could reveal differences. In both the LIM-MCMC and the Ecopath model (Lassalle et al., 2011) the highest flow estimate was for GPP. Lassalle et al. (2011) showed that flows from primary producers were $47.5 \%$ of total system throughput. High phytoplankton sedimentation and detritus production (egestion for each consumer group) estimates produced by the LIM-MCMC and the high value for consumption of DOC by bacteria - a process not included in the Ecopath model - confirmed that an active bacterial loop played a critical role in carbon recycling and in general ecosystem functioning. The convergence in estimates of the degree to which low trophic levels dominated system functioning was also observed for results at the second trophic level, mainly composed of bacteria and zooplankton.

Respiration flows constituted the main source of uncertainty in the Ecopath model (Christensen et al., 2008). In contrast to the convergence between the models' estimates of compartment input flows, there were differences in estimates of respiration flows for some compartments. The largest differences were in estimates of respiration flows for seabirds and meiofauna, with LIM-MCMC mean values 30 times higher than the Ecopath values. In the LIM-MCMC presented here, respiration flows of lower trophic levels (phytoplankton, 
bacteria, zooplankton, meiofauna and benthic invertebrates) were constrained by lower and upper eco-physiological boundaries; for the higher trophic levels, they were constrained indirectly by constraining physiological ratios such as GE or AE (Winberg, 1956; Vézina and Platt, 1988; Christensen and Pauly, 1992; Scheiffarth and Nehls, 1997; Leguerrier, 2005). The LIM-MCMC therefore provided more realistic estimates of respiration at the Bay of Biscay continental shelf than the Ecopath model.

T.., calculated as the sum of all flows, represents the size of the entire system in terms of flows (Ulanowicz, 1986) and corresponds to total system activity. The nominal Ecopath value was above the range of LIM-MCMC estimates. This is probably due to (i) a lack of consideration of autopredation (cannibalism and species groups that feed on themselves) flows in the LIM-MCMC approach; (ii) natural mortality, i.e., mortality due to causes other than predation (disease, other natural causes of death), which was included in the Ecopath model, and (iii) the importance of the estimate of detritus export in the LIM-MCMC (less cycling). All these effects may have lowered system activity (and T.. value) in the LIMMCMC, despite the fact that this model considered a higher number of interactions than the Ecopath model (e.g., additional bacterial flows and more detailed consideration of detrital processing). Internal relative ascendency $(\mathrm{Ai} / \mathrm{Ci})$ is computed with no regard for external flows (e.g., flows entering and exiting from the ecosystem) including, importantly, imports of GPP into the system. In this study the mean value of $\mathrm{Ai} / \mathrm{Ci}$ ratio was 0.34 (vs. 0.22 for the Ecopath model). The higher Ai/Ci ratio in the LIM-MCMC suggests that the ecosystem specialization was higher if model implements additional bacterial flows (e.g., flows of bacteria consumption) and more detailed consideration of detrital processing, i.e., disaggregation of particulate and dissolved organic matter into two different compartments (e.g., egestion flows, phytoplankton exudation, or indirectly by a production by viruses and cellular lysis). This conclusion reinforces the need for better representation of bacterial loop 
processes in ecosystem functioning, and thence the importance of including them in models

442 (Saint-Béat, 2012). In this case, the LIM-MCMC seems to be a relevant tool to do this.

443 Several authors referring to Ulanowicz (1986) proposed the use of internal relative 444 ascendency to discuss ecosystem maturity (Baird et al., 2007; Baird et al., 2009), which may 445 lead to possible mis-interpretation. $\mathrm{Ai} / \mathrm{Ci}, \mathrm{CI}$, and SOI values from both models indicated that 446 the food chain has a web-like structure with internal flows of intermediate complexity 447 (Libralato et al., 2008). Both models produced estimates indicative of a system less mature than similar ecosystems such as the Atlantic shelf or the Cantabrian Sea (Trites et al., 1999; Sanchez and Olaso, 2004; López, 2010).

The FCI (ratio of total flow recycled to total flow through the system) estimates from LIMMCMC were lower than the Ecopath value, indicating less cycling; a finding in line with the respective estimates of total system throughput. Intrinsic characteristics of ecosystem models should be acknowledged when analyzing the recycling index, regarding the importance of the export of detritus out of the system (sedimentation or current export) from both methods. This may, at least, partly explain the difference in FCI values. As mentioned above the Ecopath model was designed to consider more cycles and take into account autopredation and related 457 ontogenic changes (e.g., adults feeding on larvae of the same group of fish). These trophic interactions were not integrated into the LIM-MCMC and this may have contributed to the difference in FCI values. Around 10 autopredation flows described in the Ecopath model of the study area were not considered in the LIM-MCMC. Inclusion of autopredation processes would improve our LIM-MCMC. Differences in FCI estimates may also be explained by the 462 number of compartments (aggregation) used in the two models; it has been shown that the LIM-MCMC method tends to underestimate the size and complexity of food webs (Johnson et al., 2009). For estimates of some ecological network indices, the aggregation scheme explained as much variability as the difference between the inverse-derived and raw flows. 
Topological network indices tend to be fairly robust against aggregation, whereas the FCI, a functional index, is very sensitive to aggregation effects. Allesina et al. (2005) and, more recently, Fath et al. (2007), arrived at similar conclusions, stressing the interest of work on scaled indices, including ratios such as the $\mathrm{Ai} / \mathrm{Ci}$.

Both models agreed on general detritivorous system functioning, with very similar estimates of $\mathrm{D} / \mathrm{H}$ ratio. Ecological interpretation of the $\mathrm{D} / \mathrm{H}$ ratio remains controversial (Ulanowicz, 1992; Dame and Christian, 2007). Niquil et al. (2014a) emphasized that further research is needed before the $\mathrm{D} / \mathrm{H}$ ratio can be used operationally to assess the impact of disturbances on the trophic state and functioning of ecosystems. Lassalle et al. (2011) related the dominance of detritivory in the Bay of Biscay continental shelf food web to the Primary production/Respiration ratio value, which was close to 1 and therefore characteristic of a mature system in a state of organic carbon balance.

Specific recommendations for future field surveys and research emerged from work on the development of this new model of the Bay of Biscay continental shelf food web. We found that (a) there was no precise estimate of GPP in the study area, only model outputs; (b) there were no data on export of particulate organic matter from the system, it is considered more reasonable when dealing with large ecosystems to rely on expert judgments, rather than on approximate data, to shrink some confidence intervals (Johnson et al., 2009); (c) that vigilance is recommended when making comparisons between models, as comparison of indices from the Ecopath and LIM user communities revealed differences in the definitions and formulations of ENA indices. Preliminary work on translating the Ecopath routines into Matlab code is currently in progress (Kearney et al., 2012); this includes work on the harmonization of formulae for ENA indices (Guesnet, pers. comm.). This work will also require careful comparison of the Ecopath and LIM-MCMC methods using the same number 
of compartments and a similar number of entering and exiting flows. (ii) The use of different modeling methods, and more particularly model structures (number of compartments), may lead to systematic differences in results. Some differences in the estimates produced by the two modeling methods could be also easily explained, for instance the CI index is known to be sensitive to the number of modeling compartments and the number of interactions between them (Johnson et al., 2009). The different structures of the models produced by the two methods may therefore account for the observed difference in CI estimates. Such ongoing research studies will make it easier to compare model outputs and thus contribute to corroborating ecological conclusions derived from modeling studies and help to ensure that they are translated into management strategies and practice.

The LIM-MCMC of the Bay of Biscay continental shelf appears to be in line with ICES expectations. This new model was intended to provide an overview of the structural and functional properties of the food web through the calculation of holistic indices compatible with the revised ICES criteria and indicators adopted by the MSFD. New indices should include sufficient taxonomic groups to represent the full range of taxonomic groups that make up the food web in an ecosystem (ICES, 2013). Research should therefore focus on developing more integrated, functional indices which capture whole-system approaches, processes, linkages (e.g., connectance and recycling) and food-web dynamics and can relate changes in values to anthropogenic factors (Rombouts et al., 2013). As a direct perspective of use, ENA indices derived from this model should be tested through a sensitivity analysis with respect to anthropogenic climate changes and direct pressures, in line with the European directives and recommendations by working groups (OSPAR). 


\section{Conclusion}

This study has presented a new modeling tool which was used to characterize the food web status and structural and functional properties of the Bay of Biscay ecosystem. A comparison with the pre-existing Ecopath model built for the same area - the continental shelf between 30 m- and 150 m-isobaths - revealed, that both approaches resulted in similar ecological conclusions with respect to food web structure and functioning. This finding was unexpected and interesting, as the two models were developed for different purposes. Ecopath with Ecosim was originally used as a tool for ecosystem-based fishery management, whereas the LIM-MCMC method was developed to provide an overview of ecosystem functioning and a description of the system in terms of its emergent properties (e.g., ENA indices). Further analysis of the few differences in estimates produced by the two approaches is required however, as some compensatory effects may have occurred. The LIM-MCMC method potentially has several advantages over the Ecopath with Ecosim approach, and may lead to practical applications not currently possible with the Ecopath software (such as a quantification of uncertainty in the flows and food-web properties), although at present the Ecopath with Ecosim method remains the most widely used dynamic-ecosystem food-web model and still offers useful specificities for ecosystem-based management such as the distinction between detritus and discards.

The main advantages of this new approach are that it enables quantification of uncertainty in the flows and food-web properties - an important gap in some previous models - and addresses the poor integration of low-trophic-level processes in some earlier models (see for instance Pinkerton et al., 2008). Data on uncertainty, including comparison with single value estimations, are of considerable interest and research to implement similar improvements in Ecopath is already under way (Lassalle et al., 2014). An inherent feature of the LIM-MCMC method is that it allows the uncertainty of field data or of experiments to be taken into account 
539 in the model construction (inequalities definition) (Van den Meersche et al., 2009; van 540 Oevelen et al., 2010; Niquil et al., 2012). The level of uncertainty is also captured in the result 541 (with a range of possible values being estimated) (Van den Meersche et al., 2009; van 542 Oevelen et al., 2010; Niquil et al., 2012). Quantitative values for uncertainties can also be 543 used in statistical comparisons. In this study we were unable to compare estimates statistically 544 because of the large difference in sample sizes but estimates from two LIM-MCMCs could be compared, for instance models of different ecosystems, or before and after models of an ecosystem which experiences a perturbation. Some statistical tools could be used even if

547 observations were not independent (Beaugrand pers. comm.), which is not the case for LIMMCMC data owing to the Markov chain.

Another argument for quantification of uncertainty relates to the detection of shifts in the state of an ecosystem. Recent studies of abrupt changes in marine and coastal ecosystems have suggested that increasing variance is an indicator of such events (Beaugrand et al., 2008). A recent study (Niquil et al., submitted) confirmed an earlier report of a climatic shift in the Mediterranean Sea (Tomczak et al., 2013), and showed that ENA indices were sensitive to this shift and that it affected the variability of ENA index values. Such examples confirm the importance of considering the uncertainty of indices and flows. In the context of climate changes, which are expected to have a large impact on biological communities, and therefore their interactions and associated carbon flows (Hughes, 2000; Luczak et al., 2011), the LIMMCMC method could be used for sensitivity analysis, with constraints on specific biological compartments being modified according to climatic future projections. For example, after the construction of a LIM-MCMC, constraints on specific biological compartments can be easily forced by outputs from niche-based models (Raybaud et al., in revision) or biogeochemical models (Bopp et al., 2013) based on different climatic scenarios. Given the uncertainty of the LIM-MCMC constraints provided by such tools, a model based on fixed values would be 
564 unsuitable for research using such forcing. The LIM-MCMC method is also a very 565 appropriate tool to be used in this way to study human-induced impacts at an ecosystem level.

566 


\section{Acknowledgements}

568 This research was mainly supported by the DEVOTES (DEVelopment Of innovative Tools 569 for understanding marine biodiversity and assessing good Environmental Status) project 570 funded by the European Union under the 7th Framework Programme, 'The Ocean for 571 Tomorrow' Theme (grant agreement no. 308392; www.devotes-project.eu). 
572 Table 1: Compartments of the LIM-MCMC of the Bay of Biscay continental shelf. Detail

573 corresponds to the compartment species composition. Abbreviation is a three-letter code that

574 is required to identify compartments in the LIM-MCMC approach.

\begin{tabular}{|c|c|c|}
\hline Compartments & Detail & $\begin{array}{l}\text { Abbreviation } \\
\text { and code }\end{array}$ \\
\hline Marine mammals & $\begin{array}{l}5 \text { main species: the short-beaked common dolphin Delphinus } \\
\text { delphis, the striped dolphin Stenella coeruleoalba, the bottlenose } \\
\text { dolphin Tursiops truncatus, the long-finned pilot whale } \\
\text { Globicephala melas, and the harbor porpoise Phocoena phocoena }\end{array}$ & mma; 1 \\
\hline Seabirds & mainly gulls, kittiwakes, gannets, and auks & sbr; 2 \\
\hline Cephalopods & $\begin{array}{l}\text { the broadtail short-finned squid Illex coindetii, the European flying } \\
\text { squid Todarodes sagittatus, } 4 \text { Loliginidae squid species , the } \\
\text { horned octopus Eledone cirrhosa, the common octopus } O \text {. } \\
\text { vulgaris, and species of the Sepiidae family }\end{array}$ & cep; 3 \\
\hline Pelagic piscivores & $\begin{array}{c}\text { main species including the Atlantic mackerel Scomber scombrus, } \\
\text { and the horse mackerel Trachurus trachurus and tunas (albacore } \\
\text { tuna Thunnus alalunga and bluefin tuna T. thynnus) }\end{array}$ & pps; 4 \\
\hline Pelagic planktivores & $\begin{array}{c}3 \text { main species considered : the European anchovy Engraulis } \\
\text { encrasicolus, the European sprat Sprattus sprattus and the } \\
\text { European pilchard Sardina pilchardus }\end{array}$ & $\mathrm{ppl} ; 5$ \\
\hline Demersal piscivores & $\begin{array}{l}42 \text { species including the Conger eel Conger conger, the Whiting } \\
\text { pout Trisopterus luscus, the lesser spotted dogfish Scyliorhinus } \\
\text { canicula, and the European hake Merluccius merluccius }\end{array}$ & dps; 6 \\
\hline Demersal benthivores & $\begin{array}{l}\text { group of } 32 \text { species including benthivorous and suprabenthivorous } \\
\text { species such as the common sole Solea solea and the blue whiting } \\
\text { Micromesistius poutassou }\end{array}$ & $\mathrm{dbn} ; 7$ \\
\hline $\begin{array}{l}\text { Carnivorous/necropha- } \\
\text { geous invertebrates }\end{array}$ & $\begin{array}{l}\text { isopods (necrophageous), polychaetes, and crustacean decapods } \\
\text { such as the Norwegian lobster Nephrops norvegicus (carnivorous) }\end{array}$ & cbi; 8 \\
\hline Benthic deposit feeders & polychaetes, sea urchins, and sea cucumbers & dep; 9 \\
\hline Benthic suspension feeders & mainly crustaceans and bivalves & sus; 10 \\
\hline Meiofauna & largely dominated by nematodes & mef; 11 \\
\hline Macrozooplankton & $\begin{array}{c}\text { mainly composed of decapods and jelly plankton (tunicates, } \\
\text { cnidarians) }\end{array}$ & maz; 12 \\
\hline Mesozooplankton & mostly of metazoans with copepods predominating & mez; 13 \\
\hline Microzooplankton & protozoans $<200 \mu \mathrm{m}$, mostly ciliates and heterotrophic flagellates & $\operatorname{miz} ; 14$ \\
\hline Phytoplankton & $\begin{array}{l}\text { total chlorophyll a and phytoplankton production by in situ } 14 \mathrm{C} \\
\text { method }\end{array}$ & phy; 15 \\
\hline Detritus & $\begin{array}{l}\text { particulate matter (including allochtonous material, feces, } \\
\text { sedimenting matter, discards) }\end{array}$ & $\operatorname{det} ; 16$ \\
\hline
\end{tabular}




\begin{tabular}{|c|c|c|}
\hline Bacteria & benthic and pelagic bacteria & bac; 17 \\
\hline DOC & Dissolved Organic Carbon & doc; 18 \\
\hline
\end{tabular}


575 Table 2: Aggregation differences between the Ecopath model of the Bay of Biscay continental

576 shelf (Lassalle et al., 2011) and the LIM-MCMC for the same area. The compartment code for

577 the LIM-MCMC was given with the species composition in Table 1. 'DOC' means dissolved

578 organic carbon.

\begin{tabular}{|c|c|c|}
\hline $\begin{array}{c}\text { Ecopath groups } \\
\text { number }\end{array}$ & Ecopath compartments & $\begin{array}{c}\text { LIM groups } \\
\text { aggregation }\end{array}$ \\
\hline 1 & Pursuit divers seabirds & 1 \\
\hline 2 & Surface feeders seabirds & 1 \\
\hline 3 & Striped dolphins & 2 \\
\hline 4 & Bottlenose dolphins & 2 \\
\hline 5 & Common dolphins & 2 \\
\hline 6 & Long-finned pilot whales & 2 \\
\hline 7 & Harbour porpoises & 2 \\
\hline 8 & Piscivorous demersal fish & 3 \\
\hline 9 & Piscivorous and benthivorous demersal fish & 3 and 4 \\
\hline 10 & Suprabenthivorous demersal fish & 4 \\
\hline 11 & Benthivorous demersal fish & 4 \\
\hline 12 & Mackerel & 5: new group of \\
\hline 13 & Horse mackerel & pelagic piscivorous \\
\hline 14 & Anchovy & 6 \\
\hline 15 & Sardine & 6 \\
\hline 16 & Sprat & 6 \\
\hline 17 & Benthic cephalopods & 7 \\
\hline 18 & Pelagic cephalopods & 7 \\
\hline 19 & Carnivorous benthic invertebrates & 8 \\
\hline 20 & Necrophagous benthic invertebrates & 8 \\
\hline 21 & Sub-surface deposit feeders invertebrates & 9 \\
\hline 22 & Surface suspension and deposit feeders inv. & 9 and 10 \\
\hline 23 & Benthic meiofauna & 11 \\
\hline 24 & Suprabenthic invertebrates & 10 \\
\hline 25 & Macrozooplankton & 12 \\
\hline 26 & Mesozooplankton & 13 \\
\hline 27 & Microzooplankton & 14 \\
\hline 28 & Bacteria & 15 \\
\hline 29 & Large phytoplankton & 16 \\
\hline 30 & Small phytoplankton & 16 \\
\hline 31 & Discards & 17 \\
\hline 32 & Detritus & 17 \\
\hline$X$ & $X$ & 18: new group of DOC \\
\hline
\end{tabular}


581 Table 3: Comparison of respiration flows estimated by the LIM-MCMC and the Ecopath

582 model (Lassalle et al., 2011) of the Bay of Biscay continental shelf. Flow names in the LIM-

583 MCMC were composed of the three-letter code of the compartment of origin followed by the

584 three-letter code of the destination compartment. Mean corresponds to the mean flow value

585 calculated from the one million simulations. Standard deviations, minimum and maximum

586 estimates are also presented. Flows were in $\mathrm{kgC} \mathrm{km}^{-2} \cdot \mathrm{y}^{-1} \cdot{ }^{\prime} *$ ' indicated when the Ecopath

587 estimate was comprised between the maximum and minimum LIM-MCMC estimates. The

588 values of the respiration flows estimated by the LIM-MCMC with no direct comparison

589 possible to Ecopath (due to aggregation bias) were in grey.

590

LIM-MCMC

\begin{tabular}{|c|c|c|c|c|c|c|c|}
\hline Respiration flows & Name & Mean & $\begin{array}{l}\text { Standard } \\
\text { deviation }\end{array}$ & $\begin{array}{l}\text { Minimal } \\
\text { estimate }\end{array}$ & $\begin{array}{l}\text { Maximal } \\
\text { estimate }\end{array}$ & $\begin{array}{l}\text { Ecopath } \\
\text { estimate }\end{array}$ & Overlap \\
\hline marine mammals & mmaTOres & 30.51 & 23.10 & 0.00 & 214.92 & 87.95 & $*$ \\
\hline seabirds & sbrTOres & 533.44 & 189.58 & 100.84 & 1521.96 & 16.42 & \\
\hline cephalopods & cepTOres & 82.76 & 57.61 & 0.00 & 425.96 & 29.61 & $*$ \\
\hline pelagic piscivores & ppsTOres & 168.45 & 168.43 & 55.00 & 43.08 & - & - \\
\hline pelagic planktivores & pplTOres & 2581.47 & 2563.21 & 534.93 & 967.85 & 318.38 & \\
\hline demersal piscivores & dpsTOres & 32.43 & 9.72 & 10.85 & 68.97 & 318.38 & \\
\hline demersal benthivores & dbnTOres & 146.48 & 32.01 & 25.60 & 216.56 & 1250.65 & \\
\hline & cbiTOres & 285.73 & 185.02 & 0.00 & 1445.02 & 987.32 & $*$ \\
\hline benthic suspension & susTOres & & & & & & \\
\hline benthic deposit feeders & depTOres & $\begin{array}{l}563.82 \\
441.02\end{array}$ & $\begin{array}{l}199.85 \\
176.74\end{array}$ & $\begin{array}{l}33.09 \\
26.84\end{array}$ & $\begin{array}{l}1799.30 \\
1419.39\end{array}$ & $\begin{array}{c}- \\
-\end{array}$ & \\
\hline meiofauna & mefTOres & $5.78 \cdot 10^{4}$ & $2.61 .10^{4}$ & $1.76 \cdot 10^{4}$ & $1.15 \cdot 10^{5}$ & 2000.00 & \\
\hline macrozooplankton & mazTOres & $1.67 \cdot 10^{4}$ & 7554.99 & 2670.34 & $4.32 \cdot 10^{4}$ & 1999.89 & \\
\hline mesozooplankton & mezTOres & 9279.10 & 2922.53 & 2043.44 & $2.46 \cdot 10^{4}$ & $2.22 .10^{4}$ & $*$ \\
\hline microzooplankton & mizTOres & $2.41 .10^{4}$ & 6662.49 & 8239.81 & $4.90 \cdot 10^{4}$ & $1.29 \cdot 10^{5}$ & \\
\hline phytoplankton & phyTOres & $3.44 \cdot 10^{4}$ & $2.63 \cdot 10^{4}$ & 9523.87 & $9.70 \cdot 10^{4}$ & - & - \\
\hline bacteria & bacTOres & $6.17 \cdot 10^{4}$ & $1.93 .10^{4}$ & $1.89 .10^{4}$ & $1.04 \cdot 10^{5}$ & $1.94 .10^{4}$ & $*$ \\
\hline
\end{tabular}

591

592 
594 Table 4: System Omnivory Index (SOI) and Connectance Index (CI) estimated from the two 595 modeling methods.

596

\begin{tabular}{ccc} 
& LIM - MCMC & Ecopath model \\
\hline SOI & $0.19 \pm 0.03$ & 0.21 \\
CI & 0.32 & 0.21 \\
\hline
\end{tabular}

597 
601

602

603

604

605

606

607

608

609

610

611

612

613

614

615

616

617

618

619

620

621

Figure captions

Figure 1: Study area of the Bay of Biscay continental shelf and locations of the main rivers flowing into it. The shaded area corresponds to the French part of the continental shelf (between 30- and 150-m isobaths), and represents the spatial extent of the LIM-MCMC.

Figure 2: A. Distribution of the flow values estimated by the LIM-MCMC of the Bay of Biscay continental shelf, with associated standard deviations computed on one million values per flow. B. Five highest flow estimates. See Table S1 in Supplementary Material 1 for a full description of flows and numerical code. 'det' is an abbreviation for particulate detritus, and 'doc' for dissolved organic carbon .

Figure 3: Input flows distribution for compartments in common between the two modeling approaches. Black dots are the mean compartment throughputs estimated from one million simulations of the LIM-MCMC. Minimum and maximum estimates are also shown. Red triangles were the nominal values obtained from the Ecopath model. See Table 1 for compartment abbreviations and Table $\mathrm{S} 1$ for information relative to flow estimates.

Figure 4: Estimates of Total System Throughput (T..), internal relative Ascendency (Ai/Ci), Finn's Cycling Index (FCI), Detritivory on Herbivory ratio $(\mathrm{D} / \mathrm{H})$ by the two modeling approaches. Black dots were the mean ENA values estimated from one million simulations of the LIM-MCMC. Standard deviations are also shown. Blue and orange dots were minimum and maximum estimates respectively. Red triangles were the nominal values obtained from the Ecopath model. 


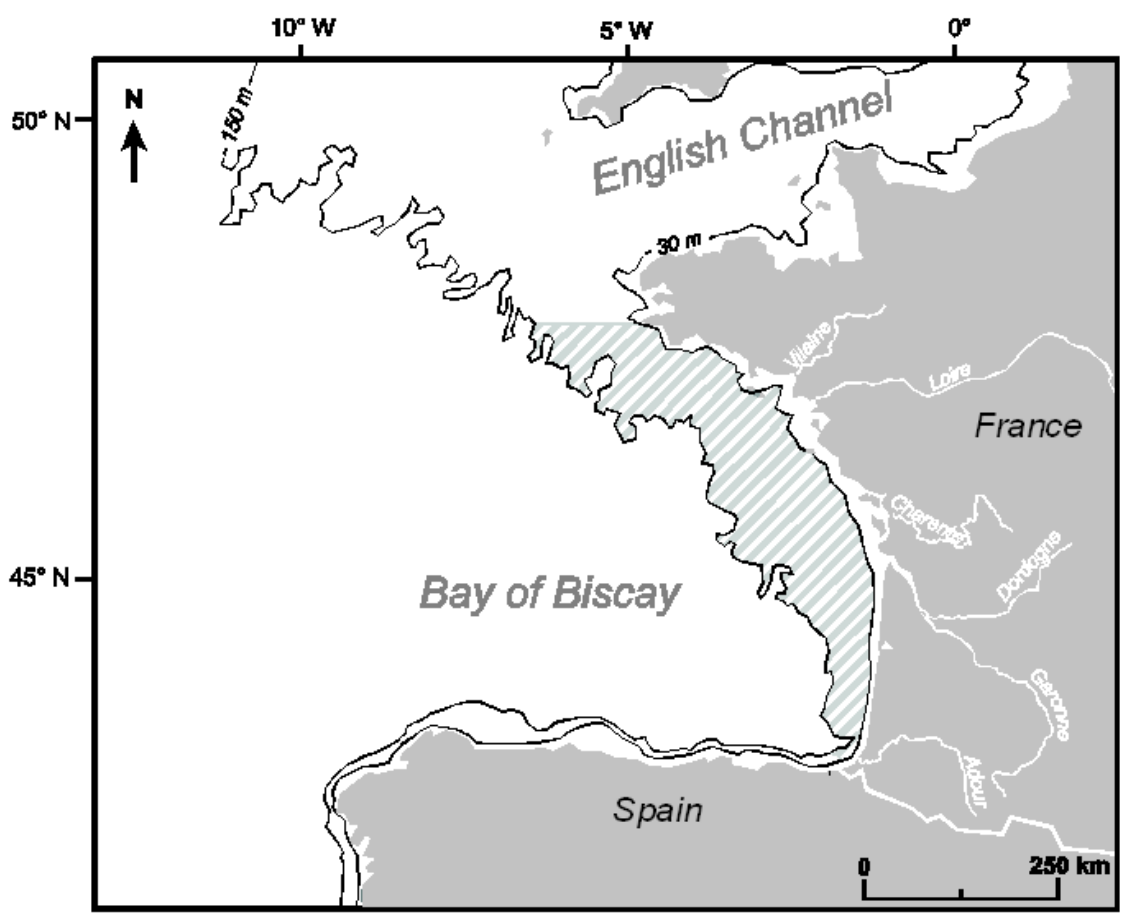

623

624 


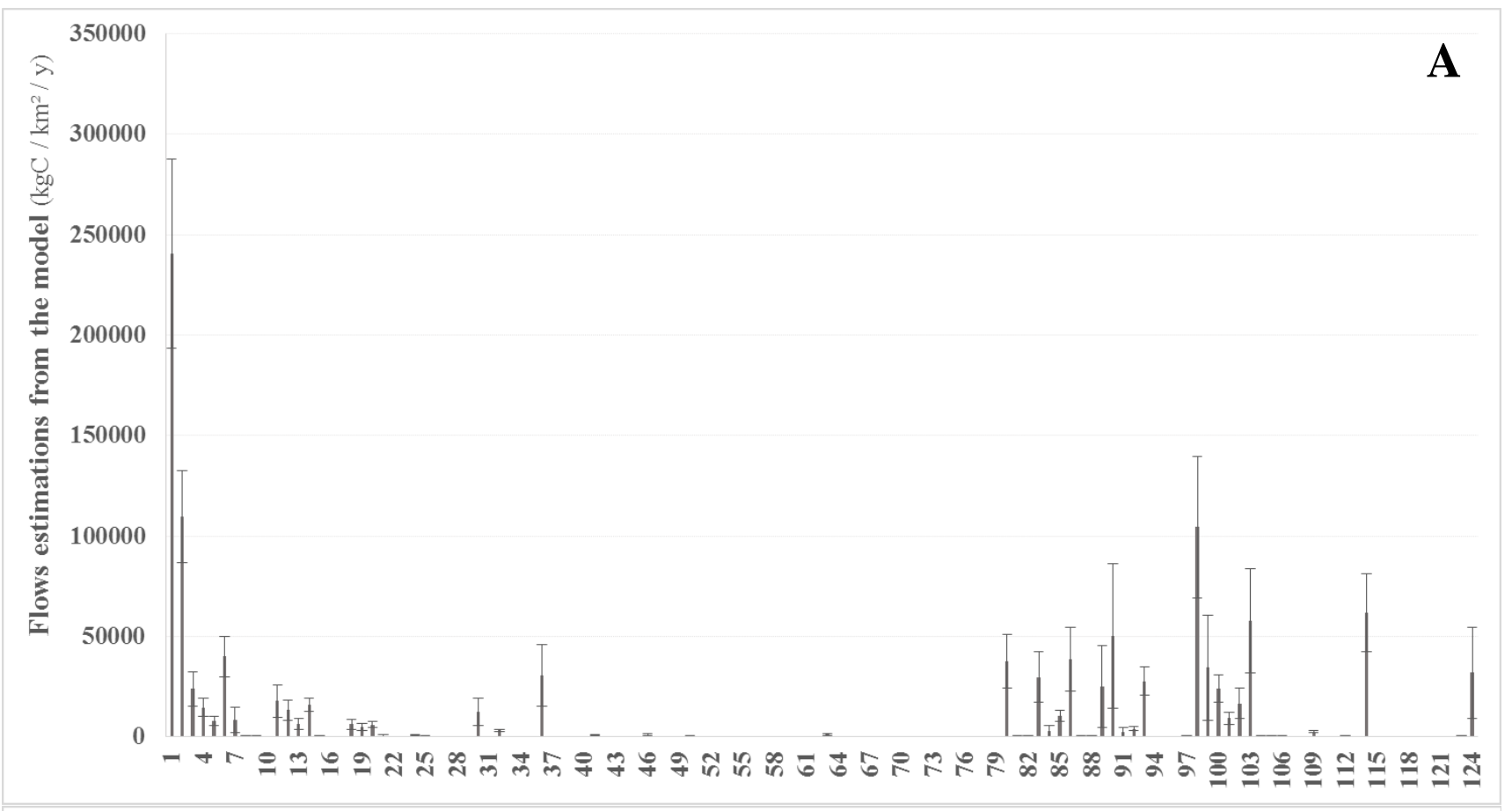

625

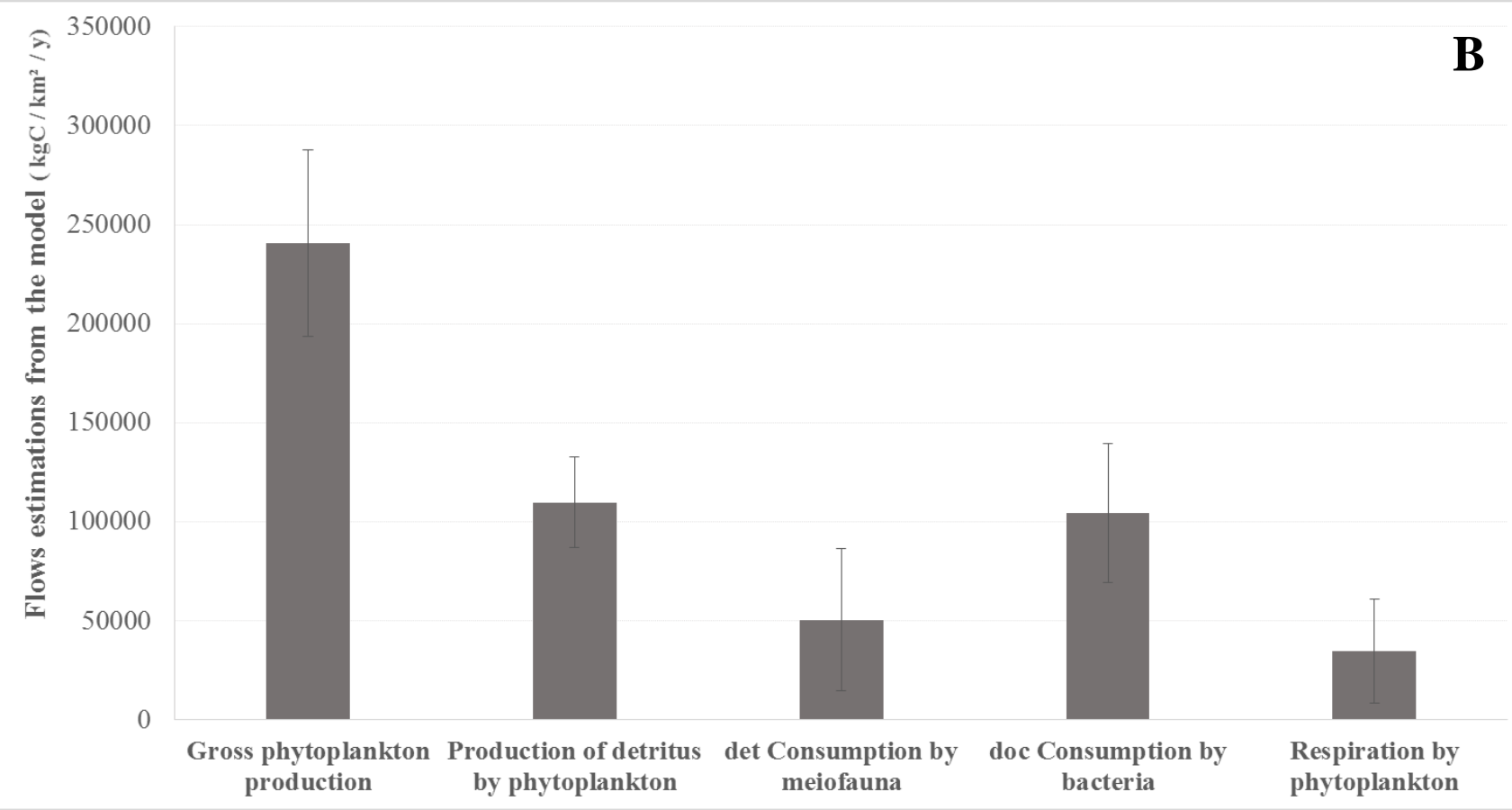

627 

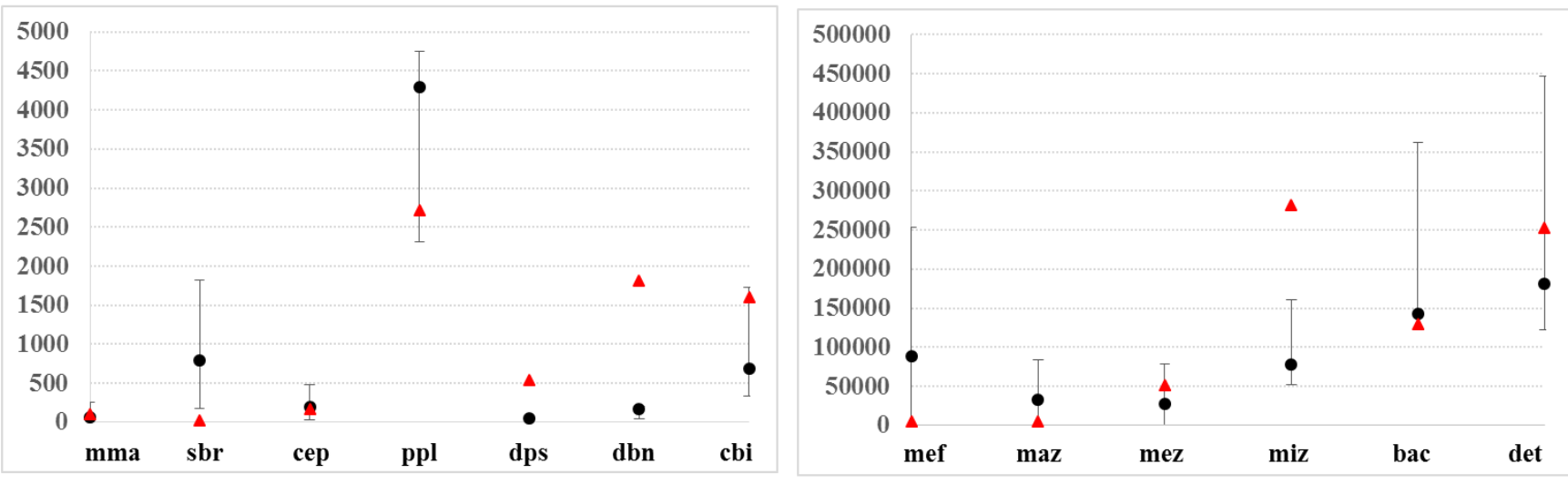

629 
630

\begin{tabular}{r|rr|r}
1000000 & & 0,4 & \\
900000 & $\Delta$ & 0,35 & $\bullet$ \\
800000 & $\bullet$ & 0,3 & \\
700000 & $\bullet$ & 0,25 & \\
600000 & & 0,2 & $\Delta$ \\
500000 & & 0,15 & \\
400000 & & 0,1 & \\
300000 & & 0,05 & \\
200000 & & 0 & $\mathbf{A i} / \mathbf{C i}$ \\
100000 & & & \\
0 & & T. &
\end{tabular}
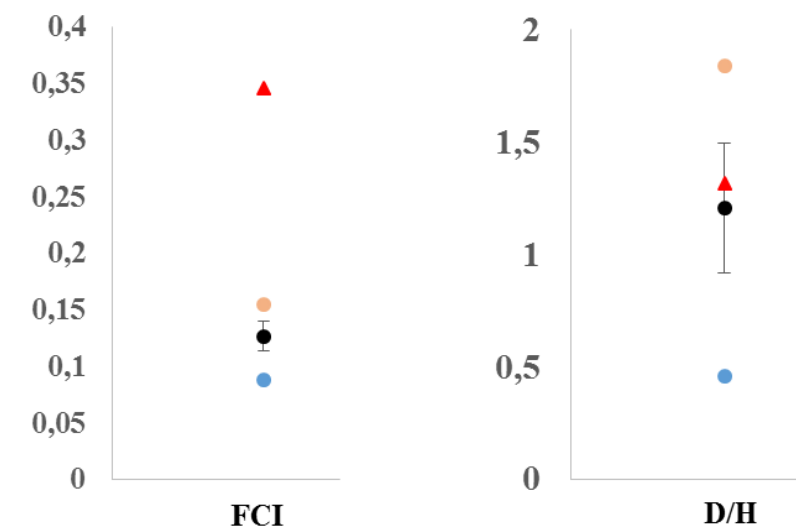

631

632 
Supplementary material:

Table S1: List of all flows $\left(\mathrm{kgC} \cdot \mathrm{km}^{-2} \cdot \mathrm{y}^{-1}\right)$ considered in the LIM-MCMC of the Bay of Biscay continental shelf. Flow names are composed of the three-letter code of the compartment of origin followed by the three-letter code of the destination compartment. Mean corresponds to the mean flow value calculated from the 1 million simulations. The mean value is given with its standard deviation.

\begin{tabular}{|c|c|c|c|c|}
\hline Flow description & Abreviation & $\begin{array}{c}\text { Flow } \\
\text { number }\end{array}$ & Mean & $\begin{array}{l}\text { Standard } \\
\text { deviation }\end{array}$ \\
\hline Gross phytoplankton production & gppTOphy & 1 & $2.41 \cdot 10^{5}$ & 47168.65 \\
\hline Production of detritus by phytoplankton & phyTOdet & 2 & $1.10 .10^{5}$ & 23059.88 \\
\hline Phytoplankton exudation & phyTOdoc & 3 & $2.39 .10^{4}$ & 8572.46 \\
\hline Grazing of phytoplankton by macrozooplankton & phyTOmaz & 4 & $1.47 .10^{4}$ & 4430.58 \\
\hline Grazing of phytoplankton by mesozooplankton & phyTOmez & 5 & 8118.38 & 2204.63 \\
\hline Grazing of phytoplankton by microzooplankton & phyTOmiz & 6 & $4.01 \cdot 10^{4}$ & 10057.47 \\
\hline Grazing of phytoplankton by meiofauna & phyTOmef & 7 & 8567.72 & 6236.27 \\
\hline Grazing of phytoplankton by benthic deposit feeders & phyTOdep & 8 & 556.91 & 277.23 \\
\hline $\begin{array}{l}\text { Consumption of phytoplankton by benthic } \\
\text { suspension feeders }\end{array}$ & phyTOsus & 9 & 408.08 & 276.39 \\
\hline $\begin{array}{c}\text { Consumption of phytoplankton by pelagic } \\
\text { planktivores }\end{array}$ & phyTOppl & 10 & 107.71 & 58.00 \\
\hline Production of detritus by microzooplankton & mizTOdet & 11 & $1.79 .10^{4}$ & 8034.80 \\
\hline Excretion of doc by microzooplankton & mizTOdoc & 12 & $1.32 .10^{4}$ & 5266.06 \\
\hline Grazing of microzooplankton by macrozooplankton & mizTOmaz & 13 & 6441.45 & 2876.43 \\
\hline Grazing of microzooplankton by mesozooplankton & mizTOmez & 14 & $1.59 .10^{4}$ & 3444.81 \\
\hline $\begin{array}{l}\text { Consumption of microzooplankton by suspension } \\
\text { feeders }\end{array}$ & mizTOsus & 15 & 358.71 & 334.80 \\
\hline $\begin{array}{c}\text { Consumption of microzooplankton by pelagic } \\
\text { planktivores }\end{array}$ & mizTOppl & 16 & 88.26 & 47.59 \\
\hline $\begin{array}{c}\text { Consumption of microzooplankton by pelagic } \\
\text { piscivores }\end{array}$ & mizTOpps & 17 & 17.66 & 6.39 \\
\hline Production of detritus by mesozooplankton & mezTOdet & 18 & 6253.57 & 2658.35 \\
\hline Excretion of doc by mesozooplankton & mezTOdoc & 19 & 4813.35 & 1671.46 \\
\hline Grazing of mesozooplankton by macrozooplankton & mezTOmaz & 20 & 6061.94 & 1547.82 \\
\hline
\end{tabular}




\begin{tabular}{|c|c|c|c|c|}
\hline $\begin{array}{l}\text { Consumption of mesozooplankton by suspension } \\
\text { feeders }\end{array}$ & mezTOsus & 21 & 474.90 & 417.92 \\
\hline $\begin{array}{l}\text { Consumption of mesozooplankton by } \\
\text { carnivorous/necrophageous invertebrates }\end{array}$ & mezTOcbi & 22 & 72.51 & 19.62 \\
\hline $\begin{array}{c}\text { Consumption of mesozooplankton by demersal } \\
\text { benthivores }\end{array}$ & mezTOdbn & 23 & 76.22 & 14.08 \\
\hline $\begin{array}{c}\text { Consumption of mesozooplankton by pelagic } \\
\text { planktivores }\end{array}$ & mezTOppl & 24 & 787.22 & 398.29 \\
\hline $\begin{array}{c}\text { Consumption of mesozooplankton by pelagic } \\
\text { piscivores }\end{array}$ & mezTOpps & 25 & 353.09 & 55.14 \\
\hline Consumption of mesozooplankton by cephalopods & mezTOcep & 26 & 5.73 & 2.36 \\
\hline $\begin{array}{l}\text { Consumption of macrozooplankton by } \\
\text { carnivorous/necrophageous invertebrates }\end{array}$ & mazTOcbi & 27 & 40.68 & 11.06 \\
\hline Consumption of macrozooplankton by cephalopods & mazTOcep & 28 & 26.51 & 16.75 \\
\hline $\begin{array}{c}\text { Consumption of macrozooplankton by demersal } \\
\text { benthivores }\end{array}$ & mazTOdbn & 29 & 38.42 & 9.69 \\
\hline Production of detritus by macrozooplankton & mazTOdet & 30 & $1.25 \cdot 10^{4}$ & 6742.81 \\
\hline $\begin{array}{l}\text { Consumption of macrozooplankton by marine } \\
\text { mammals }\end{array}$ & mazTOmma & 31 & 2.00 & 1.51 \\
\hline $\begin{array}{c}\text { Consumption of macrozooplankton by pelagic } \\
\text { planktivores }\end{array}$ & mazTOppl & 32 & 3306.36 & 540.39 \\
\hline Consumption of macrozooplankton by seabirds & mazTOsbr & 33 & 113.02 & 70.78 \\
\hline $\begin{array}{l}\text { Consumption of meiofauna by } \\
\text { carnivorous/necrophageous invertebrates }\end{array}$ & mefTOcbi & 34 & 131.52 & 34.74 \\
\hline $\begin{array}{l}\text { Consumption of meiofauna by benthic deposit } \\
\text { feeders }\end{array}$ & mefTOdep & 35 & 107.30 & 98.00 \\
\hline Production of detritus by meiofauna & mefTOdet & 36 & $3.05 \cdot 10^{4}$ & 15458.82 \\
\hline $\begin{array}{l}\text { Consumption of benthic deposit feeders by } \\
\text { carnivorous/necrophageous invertebrates }\end{array}$ & depTOcbi & 37 & 165.40 & 83.67 \\
\hline $\begin{array}{l}\text { Consumption of benthic deposit feeders by } \\
\text { cephalopods }\end{array}$ & depTOcep & 38 & 29.87 & 24.28 \\
\hline $\begin{array}{c}\text { Consumption of benthic deposit feeders by demersal } \\
\text { benthivores }\end{array}$ & depTOdbn & 39 & 33.87 & 21.98 \\
\hline $\begin{array}{c}\text { Consumption of benthic deposit feeders by demersal } \\
\text { piscivores }\end{array}$ & depTOdps & 40 & 11.98 & 7.52 \\
\hline Production of detritus by benthic deposit feeders & depTOdet & 41 & 746.02 & 341.29 \\
\hline $\begin{array}{l}\text { Consumption of benthic suspension feeders by } \\
\text { carnivorous/necrophageous invertebrates }\end{array}$ & susTOcbi & 42 & 218.55 & 91.28 \\
\hline
\end{tabular}




\begin{tabular}{|c|c|c|c|c|}
\hline $\begin{array}{l}\text { Consumption of benthic suspension feeders by } \\
\text { cephalopods }\end{array}$ & susTOcep & 43 & 30.43 & 24.80 \\
\hline $\begin{array}{c}\text { Consumption of benthic suspension feeders by } \\
\text { demersal benthivores }\end{array}$ & susTOdbn & 44 & 34.39 & 22.15 \\
\hline $\begin{array}{l}\text { Consumption of benthic suspension feeders by } \\
\text { demersal piscivores }\end{array}$ & susTOdps & 45 & 12.05 & 7.54 \\
\hline Production of detritus by benthic suspension feeders & susTOdet & 46 & 990.00 & 406.04 \\
\hline $\begin{array}{l}\text { Consumption of carnivorous/necrophageous } \\
\text { invertebrates by cephalopods }\end{array}$ & cbiTOcep & 47 & 26.93 & 14.69 \\
\hline $\begin{array}{l}\text { Consumption of carnivorous/necrophageous } \\
\text { invertebrates by demersal benthivores }\end{array}$ & cbiTOdbn & 48 & 57.93 & 14.06 \\
\hline $\begin{array}{l}\text { Consumption of carnivorous/necrophageous } \\
\text { invertebrates by demersal piscivores }\end{array}$ & cbiTOdps & 49 & 24.83 & 5.54 \\
\hline $\begin{array}{c}\text { Production of detritus by carnivorous/necrophageous } \\
\text { invertebrates }\end{array}$ & cbiTOdet & 50 & 287.92 & 185.25 \\
\hline $\begin{array}{l}\text { Consumption of carnivorous/necrophageous } \\
\text { invertebrates by pelagic piscivores }\end{array}$ & cbiTOpps & 51 & 7.98 & 2.22 \\
\hline $\begin{array}{l}\text { Consumption of demersal benthivores by } \\
\text { carnivorous/necrophageous invertebrates }\end{array}$ & dbnTOcbi & 52 & 2.58 & 0.51 \\
\hline $\begin{array}{l}\text { Consumption of demersal benthivores by } \\
\text { cephalopods }\end{array}$ & dbnTOcep & 53 & 0.17 & 0.17 \\
\hline Production of detritus by demersal benthivores & dbnTOdet & 54 & 74.35 & 29.35 \\
\hline $\begin{array}{c}\text { Consumption of demersal benthivores by demersal } \\
\text { piscivores }\end{array}$ & dbnTOdps & 55 & 5.11 & 0.48 \\
\hline $\begin{array}{l}\text { Consumption of demersal benthivores by pelagic } \\
\text { piscivores }\end{array}$ & dbnTOpps & 56 & 2.51 & 0.38 \\
\hline $\begin{array}{l}\text { Consumption of demersal benthivores by marine } \\
\text { mammals }\end{array}$ & dbnTOmma & 57 & 0.17 & 0.17 \\
\hline Consumption of demersal benthivores by seabirds & dbnTOsbr & 58 & 0.15 & 0.14 \\
\hline Production of detritus by demersal piscivores & dpsTOdet & 59 & 23.63 & 9.41 \\
\hline Consumption of demersal piscivores by cephalopods & dpsTOcep & 60 & 6.88 & 1.85 \\
\hline $\begin{array}{l}\text { Consumption of demersal piscivores by marine } \\
\text { mammals }\end{array}$ & dpsTOmma & 61 & 4.21 & 1.69 \\
\hline $\begin{array}{l}\text { Consumption of pelagic planktivores by } \\
\text { cephalopods }\end{array}$ & pplTOcep & 62 & 34.51 & 14.30 \\
\hline Production of detritus by pelagic planktivores & pplTOdet & 63 & 1272.92 & 504.55 \\
\hline $\begin{array}{c}\text { Consumption of pelagic planktivores by demersal } \\
\text { piscivores }\end{array}$ & pplTOdps & 64 & 22.09 & 6.55 \\
\hline
\end{tabular}




\begin{tabular}{|c|c|c|c|c|}
\hline $\begin{array}{l}\text { Consumption of pelagic planktivores by marine } \\
\text { mammals }\end{array}$ & pplTOmma & 65 & 35.67 & 18.90 \\
\hline $\begin{array}{c}\text { Consumption of pelagic planktivores by pelagic } \\
\text { piscivores }\end{array}$ & pplTOpps & 66 & 9.39 & 3.48 \\
\hline Consumption of pelagic planktivores by seabirds & pplTOsbr & 67 & 328.27 & 32.09 \\
\hline Consumption of pelagic piscivores by cephalopods & ppsTOcep & 68 & 33.90 & 10.09 \\
\hline Production of detritus by pelagic piscivores & ppsTOdet & 69 & 118.25 & 49.58 \\
\hline $\begin{array}{l}\text { Consumption of pelagic piscivores by marine } \\
\text { mammals }\end{array}$ & ppsTOmma & 70 & 8.88 & 6.10 \\
\hline Consumption of pelagic piscivores by seabirds & CppsTOsbr & 71 & 33.50 & 12.97 \\
\hline $\begin{array}{l}\text { Consumption of cephalopods by } \\
\text { carnivorous/necrophageous invertebrates }\end{array}$ & cepTOcbi & 72 & 6.22 & 1.68 \\
\hline $\begin{array}{c}\text { Consumption of cephalopods by demersal } \\
\text { benthivores }\end{array}$ & cepTOdbn & 73 & 2.87 & 1.31 \\
\hline Production of detritus by cephalopods & cepTOdet & 74 & 83.05 & 57.70 \\
\hline Consumption of cephalopods by demersal piscivores & cepTOdps & 75 & 1.18 & 0.30 \\
\hline Consumption of cephalopods by marine mammals & cepTOmma & 76 & 10.14 & 7.31 \\
\hline Consumption of cephalopods by pelagic piscivores & cepTOpps & 77 & 3.33 & 1.37 \\
\hline Production of detritus by seabirds & sbrTOdet & 78 & 258.16 & 102.64 \\
\hline Production of detritus by marine mammals & mmaTOdet & 79 & 30.56 & 23.16 \\
\hline Production of doc by bacteria & bacTOdoc & 80 & $3.75 .10^{4}$ & 13318.44 \\
\hline Consumption of bacteria by benthic deposit feeders & bacTOdep & 81 & 357.12 & 326.60 \\
\hline $\begin{array}{l}\text { Consumption of bacteria by benthic suspension } \\
\text { feeders }\end{array}$ & bacTOsus & 82 & 336.28 & 313.82 \\
\hline Consumption of bacteria by meiofauna & bacTOmef & 83 & $2.97 \cdot 10^{4}$ & 12463.49 \\
\hline Consumption of bacteria by macrozooplankton & bacTOmaz & 84 & 2984.05 & 2682.27 \\
\hline Consumption of bacteria by microzooplankton & bacTOmiz & 85 & $1.03 .10^{4}$ & 2712.86 \\
\hline Detritus consumption by bateria & $\operatorname{det}$ TObac & 86 & $3.85 .10^{4}$ & 15847.09 \\
\hline Detritus consumption by deposit feeders & detTOdep & 87 & 406.83 & 211.00 \\
\hline Detritus consumption by suspension feeders & $\operatorname{det}$ Osus & 88 & 271.68 & 192.76 \\
\hline Detritus dissolution & detTOdoc & 89 & $2.50 .10^{4}$ & 20519.47 \\
\hline Detritus consumption by meiofauna & detTOmef & 90 & $5.03 \cdot 10^{4}$ & 35910.84 \\
\hline Detritus consumption by macrozooplankton & $\operatorname{detTOmaz}$ & 91 & 2505.62 & 2269.69 \\
\hline Detritus consumption by mesozooplankton & detTOmez & 92 & 4119.58 & 1079.91 \\
\hline
\end{tabular}




\begin{tabular}{|c|c|c|c|c|}
\hline Detritus consumption by microzooplankton & $\operatorname{detTOmiz}$ & 93 & $2.77 \cdot 10^{4}$ & 6982.95 \\
\hline $\begin{array}{c}\text { Detritus consumption by carnivorous/necrophageous } \\
\text { invertebrates }\end{array}$ & detTOcbi & 94 & 57.48 & 35.70 \\
\hline Detritus consumption by demersal benthivores & detTOdbn & 95 & 4.08 & 1.61 \\
\hline Detritus consumption by demersal piscivores & detTOdps & 96 & 1.58 & 0.40 \\
\hline Detritus consumption by seabirds & $\operatorname{det}$ Osbr & 97 & 316.66 & 173.96 \\
\hline Doc consumption by bacteria & docTObac & 98 & $1.04 .10^{5}$ & 35129.15 \\
\hline Respiration by phytoplankton & phyTOres & 99 & $3.44 \cdot 10^{4}$ & 26328.44 \\
\hline Respiration by microzooplankton & mizTOres & 100 & $2.41 .10^{4}$ & 6662.49 \\
\hline Respiration by mesozooplankton & mezTOres & 101 & 9279.10 & 2922.53 \\
\hline Respiration by macrozooplankton & mazTOres & 102 & $1.67 .10^{4}$ & 7554.99 \\
\hline Respiration by meiofauna & mefTOres & 103 & $5.78 \cdot 10^{4}$ & 26096.67 \\
\hline Respiration by benthic deposit feeders & depTOres & 104 & 441.02 & 176.74 \\
\hline Respiration by benthic suspension feeders & susTOres & 105 & 563.82 & 199.85 \\
\hline $\begin{array}{l}\text { Respiration by carnivorous/necrophageous } \\
\text { invertebrates }\end{array}$ & cbiTOres & 106 & 285.73 & 185.02 \\
\hline Respiration by demersal benthivores & dbnTOres & 107 & 146.48 & 32.01 \\
\hline Respiration by demersal piscivores & dpsTOres & 108 & 32.43 & 9.72 \\
\hline Respiration by pelagic planktivores & pplTOres & 109 & 2563.21 & 534.93 \\
\hline Respiration by pelagic piscivores & ppsTOres & 110 & 168.43 & 55.00 \\
\hline Respiration by cephalopods & cepTOres & 111 & 82.76 & 57.61 \\
\hline Respiration by seabirds & sbrTOres & 112 & 533.44 & 189.58 \\
\hline Respiration by marine mammals & mmaTOres & 113 & 30.51 & 23.10 \\
\hline Respiration by bacteria & bacTOres & 114 & $6.17 \cdot 10^{4}$ & 19293.67 \\
\hline Export of benthic deposit feeders & depTOexp & 115 & 0.02 & 0.01 \\
\hline Export of benthic suspension feeders & susTOexp & 116 & 0.41 & 0.22 \\
\hline Export of carnivorous/necrophageous invertebrates & cbiTOexp & 117 & 3.61 & 1.93 \\
\hline Export of demersal benthivores & dbnTOexp & 118 & 16.27 & 0.14 \\
\hline Export of demersal piscivores & dpsTOexp & 119 & 11.67 & 0.86 \\
\hline Export of pelagic planktivores & pplTOexp & 120 & 23.50 & 4.04 \\
\hline Export of pelagic piscivores & ppsTOexp & 121 & 31.01 & 9.89 \\
\hline Export of cephalopods & cepTOexp & 122 & 5.37 & 1.64 \\
\hline Import of detritus & impTOdet & 123 & 502.65 & 262.80 \\
\hline
\end{tabular}


641 Table S2: Mass-balance equation of the LIM-MCMC of the Bay of Biscay continental shelf.

642 Flow names are composed of the three-letter code and number of the compartment of origin

643 followed by the three-letter code of the destination compartment.

644

\begin{tabular}{|c|c|}
\hline Compartments (abbreviation ; number) & Mass balances \\
\hline Marine mammals $(\mathrm{mma} ; 1)$ & $\begin{array}{l}\text { (mmaTOdet }+ \text { mmaTOres })-(\text { mazTOmma }+ \text { dbnTOmma } \\
+ \text { dpsTOmma }+ \text { pplTOmma }+ \text { ppsTOmma }+ \\
\text { cepTOmma })=0\end{array}$ \\
\hline Seabirds (sbr ; 2) & $\begin{array}{l}\text { (sbrTOdet }+ \text { sbrTOres })-(\text { detTOsbr }+ \text { mazTOsbr }+ \\
\text { dbnTOsbr }+ \text { pplTOsbr }+ \text { ppsTOsbr })=0\end{array}$ \\
\hline Cephalopods (cep; 3) & $\begin{array}{l}\text { (cepTOcbi + cepTOdbn + cepTOdps + cepTOpps + } \\
\text { cepTOmma + cepTOdet + cepTOres }+ \text { cepTOexp })- \\
(\text { mezTOcep }+ \text { mazTOcep }+ \text { susTOcep }+ \text { depTOcep }+ \\
\text { cbiTOcep }+ \text { dbnTOcep }+ \text { dpsTOcep }+ \text { pplTOcep }+ \\
\text { ppsTOcep })=0\end{array}$ \\
\hline Pelagic piscivores (pps ; 4) & $\begin{array}{l}\text { (ppsTOcep + ppsTOsbr + ppsTOmma + ppsTOdet }+ \\
\text { ppsTOres }+ \text { ppsTOexp })-(\text { mizTOpps }+ \text { mezTOpps }+ \\
\text { cbiTOpps }+ \text { dbnTOpps }+ \text { cepTOpps }+ \text { pplTOpps })=0\end{array}$ \\
\hline Pelagic planktivores (ppl ; 5) & $\begin{array}{l}(\text { pplTOpps + pplTOdps + pplTOcep + pplTOsbr }+ \\
\text { pplTOmma + pplTOdet + pplTOres + pplTOexp })- \\
(\text { phyTOppl + mizTOppl + mezTOppl + mazTOppl })=0\end{array}$ \\
\hline Demersal piscivores (dps; 6) & $\begin{array}{l}\text { (dpsTOcep + dpsTOmma + dpsTOdet + dpsTOres }+ \\
\text { dpsTOexp })-(\text { detTOdps }+ \text { susTOdps }+ \text { depTOdps }+ \\
\text { cbiTOdps }+ \text { dbnTOdps }+ \text { pplTOdps }+ \text { cepTOdps })=0\end{array}$ \\
\hline Demersal benthivores $(\mathrm{dbn} ; 7)$ & $\begin{array}{l}\text { (dbnTOcbi + dbnTOdps }+ \text { dbnTOpps }+ \text { dbnTOcep }+ \\
\text { dbnTOsbr }+ \text { dbnTOmma }+ \text { dbnTOdet }+ \text { dbnTOres }+ \\
\text { dbnTOexp })-(\text { detTOdbn }+ \text { mezTOdbn }+ \text { mazTOdbn }+ \\
\text { susTOdbn }+ \text { depTOdbn }+ \text { cbiTOdbn }+ \text { cepTOdbn })=0\end{array}$ \\
\hline $\begin{array}{l}\text { Carnivorous/necrophageous invertebrates } \\
\text { (cbi } ; 8)\end{array}$ & $\begin{array}{l}\text { (cbiTOdbn + cbiTOdps + cbiTOpps + cbiTOcep }+ \\
\text { cbiTOdet }+ \text { cbiTOres }+ \text { cbiTOexp) }-(\text { detTOcbi }+ \\
\text { mezTOcbi }+ \text { mazTOcbi }+ \text { mefTOcbi }+ \text { susTOcbi }+ \\
\text { depTOcbi }+ \text { dbnTOcbi }+ \text { cepTOcbi })=0\end{array}$ \\
\hline Benthic deposit feeders (dep ; 9) & $\begin{array}{l}\text { (depTOcbi + depTOdbn + depTOdps + depTOcep }+ \\
\text { depTOdet }+ \text { depTOres }+ \text { depTOexp })-(\text { phyTOdep }+ \\
\text { detTOdep + bacTOsus }+ \text { mefTOdep })=0\end{array}$ \\
\hline Benthic suspension feeders (sus ; 10) & $\begin{array}{l}\text { (susTOcbi + susTOdbn + susTOdps + susTOcep }+ \\
\text { susTOdet }+ \text { susTOres }+ \text { susTOexp })-(\text { phyTOsus }+ \\
\text { mizTOsus }+ \text { mezTOsus }+ \text { detTOsus }+ \text { bacTOsus })=0\end{array}$ \\
\hline Meiofauna (mef ; 11) & $\begin{array}{l}\text { (mefTOcbi }+ \text { mefTOdep }+ \text { mefTOdet }+ \text { mefTOres })- \\
(\text { phyTOmef }+ \text { detTOmef }+ \text { bacTOmef })=0\end{array}$ \\
\hline Macrozooplankton (maz; 12$)$ & $\begin{array}{l}\text { (mazTOcbi + mazTOdbn + mazTOppl + mazTOcep }+ \\
\text { mazTOsbr }+ \text { mazTOmma }+ \text { mazTOdet }+ \text { mazTOres })- \\
(\text { phyTOmaz }+ \text { detTOmaz }+ \text { bacTOmaz }+ \text { mizTOmaz }+ \\
\text { mezTOmaz })=0\end{array}$ \\
\hline Mesozooplankton (mez; 13) & $\begin{array}{l}\text { (mezTOdet }+ \text { mezTOdoc }+ \text { mezTOmaz }+ \text { mezTOsus }+ \\
\text { mezTOcbi }+ \text { mezTOdbn }+ \text { mezTOppl }+ \text { mezTOpps }+\end{array}$ \\
\hline
\end{tabular}




\begin{tabular}{|c|c|}
\hline & $\begin{array}{l}\text { mezTOcep + mizTOres }) \text { - (phyTOmez + detTOmez + } \\
\text { mizTOmez }=0\end{array}$ \\
\hline Microzooplankton (miz; 14$)$ & $\begin{array}{l}\text { (mizTOdet }+ \text { mizTOdoc }+ \text { mizTOmez }+ \text { mizTOmaz }+ \\
\text { mizTOsus }+ \text { mizTOppl }+ \text { mizTOpps }+ \text { mizTOres })- \\
(\text { phyTOmiz }+ \text { detTOmiz }+ \text { bacTOmiz })=0\end{array}$ \\
\hline Bacteria (bac ; 15) & $\begin{array}{l}\text { (bacTOmiz + bacTOmaz + bacTOmef }+ \text { bacTOsus }+ \\
\text { bacTOdep }+ \text { bacTOdoc }+ \text { bacTOres })-(\text { detTObac }+ \\
\text { docTObac })=0\end{array}$ \\
\hline Phytoplankton (phy ; 16) & $\begin{array}{l}\text { (phyTOdet }+ \text { phyTOdoc }+ \text { phyTOmiz }+ \text { phyTOmez }+ \\
\text { phyTOmaz }+ \text { phyTOmef }+ \text { phyTOdep }+ \text { phyTOsus }+ \\
\text { phyTOppl }+ \text { phyTOres })-(\text { gppTOphy })=0\end{array}$ \\
\hline Detritus (det ; 17) & $\begin{array}{l}\text { (detTOmiz + detTOmez + detTOmaz }+ \text { detTOmef }+ \\
\text { detTOsus }+ \text { detTOdep }+ \text { detTOcbi }+ \text { detTOdbn }+ \\
\text { detTOdps }+ \text { detTOsbr }+ \text { detTObac }+ \text { detTOdoc }+ \\
\text { detTOexp }-(\text { impTOdet }+ \text { phyTOdet }+ \text { mizTOdet }+ \\
\text { mezTOdet }+ \text { mazTOdet }+ \text { mefTOdet }+ \text { susTOdet }+ \\
\text { depTOdet }+ \text { cbiTOdet }+ \text { dbnTOdet }+ \text { dpsTOdet }+ \\
\text { pplTOdet }+ \text { ppsTOdet }+ \text { cepTOdet }+ \text { sbrTOdet }+ \\
\text { mmaTOdet })=0\end{array}$ \\
\hline Dissolved Organic Carbon (doc ; 18) & $\begin{array}{l}(\text { docTObac })-(\text { phyTOdoc }+ \text { mizTOdoc }+ \text { mezTOdoc }+ \\
\text { bacTOdoc }+ \text { detTOdoc })=0\end{array}$ \\
\hline
\end{tabular}


646 Table S3: Constraints description, with 'GPP' for gross primary production, 'R' for

647 respiration, 'Ex' for excretion, 'Det' for the loss to the detritus, 'Ing' for the total ingestion

648 (sum of all consumptions), and 'NPP' for net primary production.

Lower limit

Upper limit

References

\begin{tabular}{|c|c|c|c|}
\hline Bacteria & $\begin{array}{c}50 \% \text { of doc ingestion by } \\
\text { bacteria }\end{array}$ & $\begin{array}{c}75 \% \text { of doc ingestion by } \\
\text { bacteria }\end{array}$ & Vézina and Savenkoff, 1999 \\
\hline Phytoplankton & $5 \%$ of GPP & $30 \%$ of GPP & Vézina and Platt, 1988 \\
\hline Microzooplankton & $20 \%$ of ingestion & $\mathrm{R}+\mathrm{Ex}+$ Det $<0.75 \bullet$ Ing & $\begin{array}{l}\text { Vézina and Savenkoff, 1999; } \\
\text { Breed et al., } 2004\end{array}$ \\
\hline Mesozooplankton & $20 \%$ of ingestion & $\mathrm{R}+\mathrm{Ex}+$ Det $<0.75 \bullet$ Ing & Breed et al., 2004 \\
\hline Macrozooplankton & $20 \%$ of ingestion & N.A. & Vézina and Savenkoff, 1999 \\
\hline Meiofauna & N.A. & $-0.5 \cdot \operatorname{Ing}+0.5 \cdot \operatorname{Loss}$ to det & van Oevelen et al., 2006 \\
\hline Suspension feeders & $0.7 \bullet($ Ing - Loss to det $)$ & $-0.3 \cdot \operatorname{Ing}+0.3 \cdot$ Loss to det & van Oevelen et al., 2006 \\
\hline Deposit feeders & $0.7 \cdot($ Ing - Loss to det $)$ & $-0.3 \cdot \operatorname{Ing}+0.3 \times$ Loss to det & van Oevelen et al., 2006 \\
\hline
\end{tabular}

Excretion

Phytoplankton

$10 \%$ of NPP ; $5 \%$ of GPP

$30 \%$ of NPP ; $50 \%$ of GPP

Vézina and Platt, 1988;

Vézina and Savenkoff, 1999

$10 \%$ of ingestion

$33 \%$ of respiration

$100 \%$ of respiration

Vézina and Platt, 1988

Microzooplankton

Mesozooplankton
$10 \%$ of ingestion
Vézina and Platt, 1988 


\begin{tabular}{|c|c|c|c|}
\hline Microzooplankton & $\mathrm{AE}=50 \% ; 0.5 \cdot \mathrm{Ing}$ & $\mathrm{AE}=90 \% ; 0.1 \cdot \mathrm{Ing}$ & Vézina and Platt, 1988 \\
\hline Mesozooplankton & $\mathrm{AE}=50 \% ; 0.5 \cdot \mathrm{Ing}$ & $\mathrm{AE}=90 \% ; 0.1 \cdot \operatorname{Ing}$ & Vézina and Platt, 1988 \\
\hline Suspension feeders & $\mathrm{AE}=57 \% ; 0.43 \cdot \mathrm{Ing}$ & $\mathrm{AE}=77 \% ; 0.23 \bullet \operatorname{Ing}$ & van Oevelen et al., 2006 \\
\hline Deposit feeders & $\mathrm{AE}=40 \% ; 0,6 \cdot \mathrm{Ing}$ & $\mathrm{AE}=75 \% ; 0,25 \bullet \operatorname{Ing}$ & van Oevelen et al., 2006 \\
\hline $\begin{array}{c}\text { Carnivorous/ } \\
\text { necrophageous inverteb. }\end{array}$ & $\mathrm{AE}=40 \% ; 0,6 \bullet \operatorname{Ing}$ & $\mathrm{AE}=75 \% ; 0,25 \bullet \operatorname{Ing}$ & van Oevelen et al., 2006 \\
\hline Demersal benthivores & $\mathrm{AE}=50 \% ; 0.5 \bullet \operatorname{Ing}$ & $\mathrm{AE}=90 \% ; 0.1 \bullet \operatorname{Ing}$ & Leguerrier et al., 2004 \\
\hline Demersal piscivores & $\mathrm{AE}=50 \% ; 0.5 \bullet \mathrm{Ing}$ & $\mathrm{AE}=90 \% ; 0.1 \bullet \mathrm{Ing}$ & Leguerrier et al., 2004 \\
\hline Pelagic planktivores & $\mathrm{AE}=50 \% ; 0.5 \cdot \mathrm{Ing}$ & $\mathrm{AE}=90 \% ; 0.1 \cdot \operatorname{Ing}$ & Leguerrier et al., 2004 \\
\hline Pelagic piscivores & $\mathrm{AE}=50 \% ; 0.5 \cdot \mathrm{Ing}$ & $\mathrm{AE}=90 \% ; 0.1 \cdot \operatorname{Ing}$ & Leguerrier et al., 2004 \\
\hline Seabirds & $\begin{array}{c}\mathrm{AE}=0.43 \text { (herb. birds) } \\
0.56 \cdot \mathrm{Ing}\end{array}$ & $\begin{array}{c}\mathrm{AE}=0.8(\text { carn. birds }) \\
0.2 \cdot \text { Ing }\end{array}$ & Scheiffart and Nehls, 1997 \\
\hline
\end{tabular}

Growth efficiency

\begin{tabular}{|c|c|c|c|}
\hline Mesozooplankton & GE $=0.50$ & GE $=0.75$ & Christensen and Pauly, 1992 \\
Macrozooplankton & GE $=0.7$ & GE $=0.9$ & Christensen and Pauly, 1992 \\
\hline
\end{tabular}




\begin{tabular}{|c|c|c|c|}
\hline Suspension feeders & $\mathrm{GE}=0.7$ & $\mathrm{GE}=0.91$ & Christensen and Pauly, 1992 \\
\hline Deposit feeders & $\mathrm{GE}=0.7$ & $\mathrm{GE}=0.91$ & Christensen and Pauly, 1992 \\
\hline $\begin{array}{c}\text { Carnivorous/ } \\
\text { necrophageous inverteb. }\end{array}$ & $\mathrm{GE}=0.70$ & $\mathrm{GE}=0.90$ & Winberg, 1956 \\
\hline Demersal benthivores & $\mathrm{GE}=0.70$ & $\mathrm{GE}=0.90$ & Winberg, 1956 \\
\hline Demersal piscivores & $\mathrm{GE}=0.70$ & $\mathrm{GE}=0.90$ & Winberg, 1956 \\
\hline Pelagic planktivores & $\mathrm{GE}=0.70$ & $\mathrm{GE}=0.90$ & Winberg, 1956 \\
\hline Pelagic piscivores & $\mathrm{GE}=0.70$ & $\mathrm{GE}=0.90$ & Winberg, 1956 \\
\hline
\end{tabular}


Abril, G., Nogueira, M., Etcheber, H., Cabecadas, G., Lemaire, E., Brogueira, M.J., 2002. Behaviour of organic carbon in nine contrasting European estuaries. Estuarine Coastal and Shelf Science, 54, 241-262.

Allesina, S., Bondavalli, C., Scharler, U.M., 2005. The consequences of the aggregation of detritus pools in ecological networks. Ecological Modelling, 189, 221-232.

Baeta, A., Niquil, N., Marques, J.C., Patrício, J., 2011. Modelling the effects of eutrophication, mitigation measures and an extreme flood event on estuarine benthic food webs. Ecological Modelling 222, 209-1221.

Baird, D., Asmus, H., Asmus, R., 2007. Trophic dynamics of eight intertidal communities of the Sylt-Rømø Bight ecosystem, northern Wadden Sea. Marine Ecology Progress Series, 351, 25-41.

Baird, D., Fath, B.D., Ulanowicz, R.E., Asmus, H., Asmus, R., 2009. On the consequences of aggregation and balancing of networks on system properties derived from ecological network analysis. Ecological Modelling, 220, 3465-3471.

Beaugrand, G., Edwards, M., Brander, K., Luczak, C., Ibanez, F., 2008. Causes and projections of abrupt climate-driven ecosystem shifts in the North Atlantic. Ecology letters, $11,1157-1168$.

Bopp, L., Resplandy, L., Orr, J.C., Doney, S.C., Dunne, J.P., Gehlen, M., Halloran, P., Heinze, C., Ilyina, T., Seferian, R., Tjiputra, J., Vichi, M., 2013. Multiple stressors of ocean ecosystems in the 21st century: projections with CMIP5 models. Biogeosciences, 10, 62256245 .

Breed, G., Jackson, G., Richardson, T., 2004. Sedimentation, carbon export and food web structure in the Mississippi River plume described by inverse analysis. Marine Ecology Progress Series 278, 35-51.

Certain, G., Masse, J., Van Canneyt, O., Petitgas, P., Doremus, G., Santos, M.B., Ridoux, V., 2011. Investigating the coupling between small pelagic fish and marine top predators using data collected from ecosystem-based surveys. Marine Ecology Progress Series, 422, 23-39.

Certain, G., Ridoux, V., Van Canneyt, O., Bretagnolle, V., 2008. Delphinid spatial distribution and abundance estimates over the shelf of the Bay of Biscay. Ices Journal of Marine Science, 65, 656-666.

Christensen, V., Pauly, D., 1992. ECOPATH-II - A software for balancing steady-state ecosystem models and calculating network characteristics. Ecological Modelling, 61, 169185.

Christensen, V., Walters, C.J., Pauly, D., Forrest, R., 2008. Ecopath with Ecosim Version 6: User Guide.

Coll, M., Palomera, I., Tudela, S., 2009. Decadal changes in a NW Mediterranean Sea food web in relation to fishing exploitation. Ecological Modelling, 220, 2088-2102.

Dame, J.K., Christian, R.R., 2007. A statistical test of network analysis: Can it detect differences in food web properties? Ecosystems, 10, 906-923.

Davidson, K., 1996. Modelling microbial food webs. Marine Ecology Progress Series, 145, 279-296.

Decision 2010/477/EU. COMMISSION DECISION of 1 September 2010 on criteria and methodological standards on good environmental status of marine waters. Official Journal of the European Union, L 232/14.

Directive 2008/56/EC of the European Parliament and of the Council of 17 June 2008 establishing a framework for community action in the field of marine environmental policy (Marine Strategy Framework Directive) . Official Journal of the European Union, L 164/19. 
Donali, E., Olli, K., Heiskanen, A.S., Andersen, T., 1999. Carbon flow patterns in the planktonic food web of the Gulf of Riga, the Baltic Sea: a reconstruction by the inverse method. Journal of Marine Systems, 23, 251-268.

Fath, B.D., Scharler, U.M., Ulanowicz, R.E., Hannon, B., 2007. Ecological network analysis: network construction. Ecological Modelling, 208, 49-55.

Finn, J.T., 1980. Flow-analysis of models of the Hubbard Brook ecosystem. Ecology, 61, 562571.

Frontier, S., Pichod-Viale, D., Leprêtre, A., Davoult, D., Luczak, C., 2008. Ecosystèmes. Structure, Fonctionnement, Evolution.

Hughes, L., 2000. Biological consequences of global warming: Is the signal already apparent? Trends in Ecology and Evolution, 15, 56-61.

ICES, 2004. Report of the ICES advisory committee on fisheries management and advisory committee on ecosystems.

ICES, 2005a. Report of the working group of cephalopod fisheries and life history (WGCEPH).

ICES, 2005b. Report of the working group on the assessment of mackerel, horse mackerel, sardine and anchovy (WGMHSA).

ICES, 2013. OSPAR special request on review of the technical specification and application of common indicators under D1, D2, D4, and D6. In v. ICES Advice (Ed.).

Irigoien, X., Fernandes, J.A., Grosjean, P., Denis, K., Albaina, A., Santos, M., 2009. Spring zooplankton distribution in the Bay of Biscay from 1998 to 2006 in relation with anchovy recruitment. Journal of Plankton Research, 31, 1-17.

Johnson, G.A., Niquil, N., Asmus, H., Bacher, C., Asmus, R., Baird, D., 2009. The effects of aggregation on the performance of the inverse method and indicators of network analysis. Ecological Modelling, 220, 3448-3464.

Kearney, K.A., Stock, C., Aydin, K., Sarmiento, J.L., 2012. Coupling planktonic ecosystem and fisheries food web models for a pelagic ecosystem: Description and validation for the subarctic Pacific. Ecological Modelling, 237, 43-62.

Kones, J.K., Soetaert, K., van Oevelen, D., Owino, J.O., Mavuti, K., 2006. Gaining insight into food webs reconstructed by the inverse method. Journal of Marine Systems, 60, 153-166. Labry, C., Herbland, A., Delmas, D., 2002. The role of phosphorus on planktonic production of the Gironde plume waters in the Bay of Biscay. Journal of Plankton Research, 24, 97-117.

Lampert, L., 2001. Dynamique saisonnière et variabilité pigmentaire des populations phytoplanctoniques dans l'Atlantique Nord (Golfe de Gascogne). Oceanologie biologique (p. 294). Brest: Université de Bretagne Occidentale, Brest, France, 294 p.

Lassalle, G., Bourdaud, P., Saint-Béat, B., Rochette, S., Niquil, N., 2014. A toolbox to evaluate data reliability for whole-ecosystem models: Application on the Bay of Biscay continental shelf food-web model. Ecological Modelling, 285, 13-21.

Lassalle, J., Lobry, J., Le Loc'h, F., Bustamante, P., Certain, G., Delmas, D., Dupuy, C., Hily, C., Labry, C., Le Pape, O., Marquis, E., Petitgas, P., Pusineri, C., Ridoux, V., Spitz, J., Niquil, N., 2011. Lower trophic levels and detrital biomass control the Bay of Biscay continental shelf food web: Implications for ecosystem management. Progress in Oceanography, 91, 561-575.

Le Loc'h, F., 2004. Structure, fonctionnement, évolution des communautés benthiques des fonds meubles exploités du plateau continental Nord-Gascogne. Vol. Thesis (p. 378). Brest, France: Université de Bretagne Occidentale.

Leguerrier, D., 2005. Construction et étude d'un modèle de réseau trophique de la vasière de Brouage (bassin de Marennes Oléron, France). Prise en compte de la saisonnalité et des échanges physiques pour la synthèse constructive des connaissances sur une zone intertidale d'une région tempérée., Vol. Thesis (p. 655): University of La Rochelle. 
Leguerrier, D., Niquil, N., Petiau, A., Bodoy, A., 2004. Modeling the impact of oyster culture on a mudflat food web in Marennes-Oléron Bay (France). Marine Ecology Progress Series. 273, 147-161. Microbial Loop on Aquatic Food Webs. 7th International Congress on Environmental Modelling and Software (p. 7). San Diego, CA, USA.

Libralato, S., Coll, M., Tudela, S., Palomera, I., Pranovi, F., 2008. Novel index for quantification of ecosystem effects of fishing as removal of secondary production. Marine Ecology Progress Series, 355, 107-129.

Luczak, C., Beaugrand, G., Jaffré, M., Lenoir, S., 2011. Climate change impact on Balearic shearwater through a trophic cascade. Biology Letters, 7, 702-705.

López Jimeno, J., 2010. A Mass Balance Model of the Bay of Biscay Ecosystem. AZTITecnalia, Marine Research Division, Area of Pelagic Resources Management, Vol. Master. Donostia-San Sebastián, Spain.

Marquis, E., Niquil, N., Delmas, D., Hartmann, H.J., Bonnet, D., Carlotti, F., Herbland, A., Labry, C., Sautour, B., Laborde, P., Vézina, A., Dupuy, C., 2007. Inverse analysis of the planktonic food web dynamics related to phytoplankton bloom development on the continental shelf of the Bay of Biscay, French coast. Estuarine Coastal and Shelf Science, 73, 223-235.

Niquil, N., Pouvreau, S., Sakka, A., Legendre, L., Addessi, L., Le Borgne, R., Charpy, L., Delesalle, B., 2001. Trophic web and carrying capacity in a pearl oyster farming lagoon (Takapoto, French Polynesia). Aquatic Living Resources, 14, 165-174.

Niquil, N., Saint-Béat, B., Johnson, G.A., Soetaert, K., van Oevelen, D., Bacher, C.,Vézina, A.F., 2012. Inverse modeling in modern ecology and application to coastal ecosystems. Treatise on Estuarine and Coastal Science, Vol. 9 (pp. 115-133): Waltham: Academic Press. Niquil, N., Baeta, A., Marques, J.C., Chaalali, A., Lobry, J., Patrício, J., 2014a. How does an estuarine food web react to disturbances? Lindeman's perspective Marine Ecology Progress Series.

Niquil, N., Le Loc'h, F., Tecchio, S., Chaalali, A., Vouriot, P., Mialet, B., Fizzala, X., Féral, J.-P., Lamare S., Dauvin J.-C., Safi, G., 2014b. Trans-Channel Forum Proceedings, Science and Governance of the Channel Marine Ecosystem, 14 -15

Niquil N., Astorg L., Tecchio S., Chaalali A., Safi G., Raoux A., Patricio J., Lynam C., Heymans J.J., Tomczak M.T., Hattab T., Le Loc'h F., Piroddi C. Shifting states of a Mediterranean food web evidenced by ecological network analysis. Progress in Oceanography. Submitted.

Pace, M.L., Glasser, J.E., Pomeroy, L.R., 1984. A simulation analysis of continental shelf food webs. Marine Biology 82, 47-63.

Patrício, J., Ulanowicz, R., Pardal, M.A., Marques, J. C., 2004. Ascendency as ecological indicator: a case study on estuarine pulse eutrophication. Estuarine, Coastal and Shelf Science 60, 23-35.

Pauly, D., Christensen, V., Dalsgaard, J., Froese, R., Torres, F., 1998. Fishing down marine food webs. Science, 279, 860-863.

Pinkerton, M.H., Bradford-Grieve, J.M., Hanchet, S.M. 2008. A preliminary balanced trophic model of the ecosystem of the Ross Sea, Antarctica, with emphasis on apex predators. Working paper presented to WG-EMM-08/42, St Petersburg, Russia.

Planque, B., Lazure, P., Jegou, A.M., 2004. Detecting hydrological landscapes over the Bay of Biscay continental shelf in spring. Climate Research, 28, 41-52.

Pranovi, F., Link, J.S., 2009. Ecosystem exploitation and trophodynamic indicators: A comparison between the Northern Adriatic Sea and Southern New England. Progress in Oceanography, 81, 149-164. 
Raybaud, V., Bacha, M., Amara, R., Beaugrand, G., 2014. Climate-induced changes in the geographical range of the European anchovy (Engraulis encrasicolus), Global Change Biology, In revision.

Riemann, B.,Sorensen, H.M.,Bjornsen, P.K.,Horsted, S.J.,Jensen, L.M.,Nielsen, T.G.,Sondergaard, M., 1990. Carbon budgets of the microbial food web in estuarine enclosures. Marine Ecology Progress Series, 65, 159-170.

Rioual, F., 2012. Modélisation écosystémique de l'estuaire et du nord du golfe du SaintLaurent. M. Sc. Thesisr, Université de Bretagne Occidentale, Brest, France, 35 p.

Rochet, M.J., Daurès, F., Trenkel, V.M., 2012. Capacity management, not stock status or economics, drives fleet dynamics in the Bay of Biscay ecosystem on a decadal time scale.Canadian Journal of Fisheries and Aquatic Sciences, 69, 695-710.

Rombouts, I., Beaugrand, G., Fizzala, X., Gaill, F., Greenstreet, S.P.R., Lamare, S., Le Loc'h, F., McQuatters-Gollop, A., Mialet, B., Niquil, N., Percelay, J., Renaud, F., Rossberg, A.G., Féral, J.P., 2013. Food web indicators under the Marine Strategy Framework Directive: From complexity to simplicity? Ecological Indicators, 29, 246-254

Saint-Béat, B., 2012. Modélisation du rôle du biofilm dans le fonctionnement du réseau trophique de la vasière de Brouage (Bassin de Marennes-Oléron): influence sur les flux de Carbone et conséquences sur la stabilité. PhD Thesis,Université de La Rochelle, France, 316 p.

Saint-Béat, B., Dupuy, C., Bocher, P., Chalumeau, J., De Crignis, M., Fontaine, C., Guizien, K., Lavaud, J., Lefebvre, S., Montanie, H., Mouget, J.L., Orvain, F., Pascal, P.Y., Quaintenne, G., Radenac, G., Richard, P., Robin, F., Vézina, A.F., Niquil, N., 2013. Key features of intertidal food webs that support migratory shorebirds. Plos One, 8, 17.

Sanchez, F., Olaso, I., 2004. Effects of fisheries on the Cantabrian Sea shelf ecosystem. Ecological Modelling, 172, 151-174.

Savenkoff, C., Castonguay, M. , Chabot, D., Hammill, M.O., Bourdages, H., Morissette, L., 2007. Changes in the northern Gulf of St. Lawrence ecosystem estimated by inverse modelling: Evidence of a fishery-induced regime shift? Estuarine, Coastal, and Shelf Science, 73 (3-4), 711-724.

Scheiffarth, G., Nehls, G., 1997. Consumption of benthic fauna by carnivorous birds in the Wadden Sea. Helgolander Meeresuntersuchungen, 51, 373-387.

Soetaert, K., Franco, M., Lampadariou, N., Muthumbi, A., Steyaert, M., Vandepitte, L., vanden Berghe, E., Vanaverbeke, J., 2009. Factors affecting nematode biomass, length and width from the shelf to the deep sea. Marine Ecology Progress Series, 392, 123-132.

Tomczak, M.T., Heymans, J.J., Yletyinen, J., Niiranen, S., Otto, S.A., Blenckner, T., 2013. Ecological network indicators of ecosystem status and change in the Baltic sea. Plos One, 8, 11.

Trites, A.W., Livingston, P.A., Vasconcellos, M.C., Mackinson, S., Springer, A.M., Pauly, D., 1999. Ecosystem change and the decline of marine mammals in the eastern Bering Sea: testing the ecosystem shift and commercial whaling hypotheses. . Fisheries Centre Research Reports, 7.

Ulanowicz, R.E., 1986. Growth \& development: ecosystems phenomenology. NY: SpringerVerlag.

Ulanowicz, R.E., 1992. Ecosystem Health. In: R Costanza, BG Norton, Haskell BD (eds.) Ecosystem health: new goals for environmental management, Island Press, Washington, DC, 190-225.

Van den Meersche, K., Soetaert, K., Van Oevelen, D., 2009. xsample(): an R function for sampling linear inverse problems. Journal of Statistical Software, 30, 1-15. 
van Oevelen, D., Soetaert, K., Middelburg, J.J., Herman, P.M.J., Moodley, L., Hamels,

847 I.,Moens, T., Heip, C.H.R., 2006. Carbon flows through a benthic food web: Integrating 848 biomass, isotope and tracer data. Journal of Marine Research, 64, 453-482.

849 van Oevelen, D., Van den Meersche, K., Meysman, F., Soetaert, K., Middelburg, J.J., Vézina, 850 A.F., 2010. Quantitative reconstruction of food webs using linear inverse models. Ecosystems, 851 13, 32-45.

852 Varela, M., 1996. Phytoplankton ecology in the Bay of Biscay. Scientia Marina, 60, 45-53.

853 Vézina, A.F., Pace, M.L., 1994. An inverse model analysis of planktonic food webs in 854 experimental lakes. Canadian Journal of Fisheries and Aquatic Sciences, 51, 2034-2044.

855 Vézina, A.F., Platt, T., 1988. Food web dynamics in the ocean. 1. Best-estimates of flow 856 networks using inverse methods. Marine Ecology Progress Series, 42, 269-287.

857 Vézina, A.F., Savenkoff, C., 1999. Inverse modeling of carbon and nitrogen flows in the 858 pelagic food web of the northeast subarctic Pacific. Deep-Sea Research Part II-Topical 859 Studies in Oceanography, 46, 2909-2939.

860 Winberg, G.G., 1956. Rate of metabolism and food requirements of fishes. Fisheries Research Board of Canada, Translation Series 194, 253 p. 